\title{
Dominant-Negative Inhibition of M-Like Potassium Conductances in Hair Cells of the Mouse Inner Ear
}

\author{
Jeffrey R. Holt, Eric A. Stauffer, David Abraham, and Gwenaëlle S. G. Géléoc \\ Departments of Neuroscience and Otolaryngology, University of Virginia, Charlottesville, Virginia 22908
}

\begin{abstract}
Sensory hair cells of the inner ear express multiple physiologically defined conductances, including mechanotransduction, $\mathrm{Ca}^{2+}, \mathrm{Na}^{+}$, and several distinct $\mathrm{K}^{+}$conductances, all of which are critical for normal hearing and balance function. Yet, the molecular underpinnings and their specific contributions to sensory signaling in the inner ear remain obscure. We sought to identify hair-cell conductances mediated by KCNQ4, which, when mutated, causes the dominant progressive hearing loss DFNA2. We used the dominant-negative pore mutation G285S and packaged the coding sequence of KCNQ4 into adenoviral vectors. We transfected auditory and vestibular hair cells of organotypic cultures generated from the postnatal mouse inner ear. Cochlear outer hair cells and vestibular type I cells that expressed the transfection marker, green fluorescent protein, and the dominant-negative KCNQ4 construct lacked the M-like conductances that typify nontransfected control hair cells. As such, we conclude that the M-like conductances in mouse auditory and vestibular hair cells can include KCNQ4 subunits and may also include KCNQ4 coassembly partners. To examine the function of M-like conductances in hair cells, we recorded from cells transfected with mutant KCNQ4 and injected transduction current waveforms in current-clamp mode. Because the M-like conductances were active at rest, they contributed to the very low potassium-selective input resistance, which in turn hyperpolarized the resting potential and significantly attenuated the amplitude of the receptor potential. Modulation of M-like conductances may allow hair cells the ability to control the amplitude of their response to sensory stimuli.
\end{abstract}

Key words: potassium conductance; potassium channel; hair cell; utricle; saccule; semicircular canal; mechanotransduction; KCNQ

\section{Introduction}

Hair cells encode mechanosensory information within the waveform of graded receptor potentials that propagate from the apical mechanosensitive hair bundle to the basal afferent synapse. There are several important general questions regarding hair-cell biology. How is information encoded within the sensory cells? How is the information modified as it propagates from the site of transduction to the site of neurotransmission? What are the signaling molecules involved and why do mutations in those molecules cause sensory deficits? With this information, development of rational strategies for restoration of sensory function in patients who suffer inner ear disorders can commence. To begin to address these questions, we examined the physiological identity and function of KCNQ conductances in auditory and vestibular hair cells.

Mutations in four of the five members of the KCNQ family of potassium channel subunits cause inherited human disease. KCNQ1 mutations cause Jervell and Lange-Nielsen syndrome, which is characterized by cardiac dysfunction and deafness. Mu-

Received April 6, 2007; revised June 28, 2007; accepted July 4, 2007.

This work was supported by National Institutes of Health/National Institute on Deafness and Other Communication Disorders Grants DC05439 (J.R.H.) and DC006183 (G.S.G.G.). We thank Drs. Thomas Jentsch for providing the hKCNQ4 clone, Kirk Beisel for the mKCNQ4 clone, and Bechara Kachar for the KCNQ4 antibody. We also thank members of the Holt/Géléoc lab for helpful discussions.

Correspondence should be addressed to Dr. Jeffrey R. Holt, Department of Neuroscience, University of Virginia, Medical Research Building 4, Room 5126, Box 801392, Charlottesville, VA 22908-1392. E-mail: jeffholt@virginia.edu.

DOI:10.1523/JNEUROSCI.2085-07.2007

Copyright $\odot 2007$ Society for Neuroscience $\quad$ 0270-6474/07/278940-12\$15.00/0 tations in either KCNQ2 or KCNQ3 cause benign neonatal epilepsy. Mutations in KCNQ4 cause the nonsyndromic, dominant progressive hearing loss, DFNA2 (Kubisch et al., 1999; Kharkovets et al., 2000). Although the significance of the KNCQ gene family for human health is clear, the precise function of KCNQ subunits remains obscure. Here, we investigated the physiological manifestation of KCNQ4 expression in auditory and vestibular hair cells and why mutations in KCNQ4 cause inner-ear dysfunction.

Hair cells express about a dozen physiologically distinct potassium-permeable conductances. As a result, identification of the molecular substrate for each conductance has not been trivial. For example, although there is substantial evidence for KCNQ4 expression in hair cells (Kubisch et al., 1999; Beisel et al., 2000, 2005; Kharkovets et al., 2000, 2006; Hurley et al., 2006; RochaSanchez et al., 2007), identification of its physiological correlate has been confounded by the significant difference between the biophysical properties of KCNQ4 expressed in heterologous cells and those of hair-cell potassium conductances. In heterologous cells, KCNQ4 expression results in large, slowly activating, noninactivating currents with broad voltage dependence centered around -20 to $-30 \mathrm{mV}$ (Kubisch et al., 1999; Schroder et al., 2001; Sogaard et al., 2001; Hougaard et al., 2004; Chambard and Ashmore, 2005). Based on the localization in cochlear hair cells and vestibular type I hair cells, it was suggested that KCNQ4 expression may correspond to the low-voltage-activated potassium conductances $G_{\mathrm{K}, \mathrm{n}}$ and $G_{\mathrm{K}, \mathrm{L}}$, respectively (Holt and Corey, 1999; Trussell, 2000). Yet, in hair cells, $G_{K, n}$ and $G_{K, L}$ have steep 
voltage dependence centered around -60 to $-80 \mathrm{mV}$. Previously, Kharkovets et al. (2006) showed that targeted deletion of KCNQ4 resulted in loss of $G_{\mathrm{K}, \mathrm{n}}$ in cochlear outer hair cells, but they did not examine the identity of KCNQ4 conductances in vestibular hair cells.

Here, we use adenoviral delivery of dominant-negative KCNQ4 to confirm the identity of the KCNQ4 conductance in cochlear hair cells, to reveal the identity of the KCNQ4 conductance in vestibular hair cells, and to extend both observations with specific inhibition of the conductances to demonstrate their contribution to sensory signaling in the inner ear.

\section{Materials and Methods}

$R T$-PCR. For quantitative PCR, tissues were harvested from embryonic day 15 (E15) to postnatal day 9 (P9) mice purchased from Hilltop Labs (Scottdale, PA) or Taconic Farms (Hudson, NY). Timed pregnant females were assessed as described previously (Géléoc and Holt, 2003; Géléoc et al., 2004). Embryos were removed by caesarean section around midday and killed by decapitation. At each developmental stage, 20 utricles were excised and collected in a timely manner without previous enzymatic treatment. Total mRNA was then purified to produce the cDNA bank. mRNA was prepared using the RNA-aqueous macrokit (Ambion, Austin, TX) and contamination by genomic DNA was prevented by treating the sample with the TurboDNase (Ambion). Reverse transcription was performed using the Iscript kit (Bio-Rad, Hercules, CA) and $2 \mu \mathrm{l}$ of total mRNA. A no-reverse transcriptase (RT) control (same preparation, but lacking the reverse-transcription enzyme) was produced simultaneously. Expression level was tested on a housekeeping gene (ribosomal 29S) for the RT and no-RT samples using Sybrgreen real-time PCR. Ribosomal $29 S$ expression was tested with the following primer set: sense, 5'-GGAGTCACCCACGGAAGTTCGG-3'; antisense, 5'-GGAAGCACTGGCGGCACATG-3' (melting temperature, $\sim 62^{\circ} \mathrm{C}$ ). Once lack of DNA contamination was confirmed in the no-RT control, the rest of the total mRNA sample was reverse transcribed, aliquoted, and stored at $-80^{\circ} \mathrm{C}$. cDNA levels were analyzed using a spectrophotometer (ND100; Nanodrop, Wilmington, DE), which revealed a final concentration of $\sim 550 \mathrm{ng}$ double-stranded DNA per microliter of reverse transcription solution. KCNQ4 expression was analyzed in each sample using a real-time primer set designed using the Beacon Designer software: sense, 5' -TCTCCGCACAGACGCTCAG-3'; Antisense, 5' -TCAAGTAAGAGAGGAGTCC AGAGG-3' (melting temperature, $\sim 60^{\circ} \mathrm{C}$ ). Experimental conditions were optimized using a plasmid that carried wild-type KCNQ4. The size of the cDNA amplified (132 bp) for our primer set were confirmed by agarose gel electrophoresis. A melt curve increasing the set point temperature after cycle 2 by $0.5^{\circ} \mathrm{C}$ was also obtained at the end of the protocol to confirm the specificity of our primer set. One single product melting at $89^{\circ} \mathrm{C}$ was obtained for all experiments. Expression of house-keeping genes (29S) and hair-cellspecific genes $(M y o 7 a)$ was also monitored in our preparation. A standard curve was obtained for KCNQ4 using a serial dilution of the wildtype KCNQ4 in the PAdTrack-cytomegalovirus $(\mathrm{cmv})$ shuttle plasmid (original concentration, $18 \mathrm{ng} / \mathrm{ul}$ ). A standard curve was generated and used to estimate the level of KCNQ4 at each developmental stage. Analysis was performed using Origin 6.1 (MicroCal Software, Northampton, MA).

Generation of adenoviral vectors. The coding sequence of human KCNQ4-G285S was a kind gift from Dr. Thomas Jentsch (Max Delbrück Center for Molecular Medicine, Berlin, Germany) (Kubisch et al., 1999) and mouse KCNQ4 ( $m K C N Q 4)$ was a gift from Dr. Kirk Beisel (Creighton University, Omaha, NE) (Beisel et al., 2005). Mutation of G285 to S285 in the p-loop of mKCNQ4 was performed with the Transformer site-directed mutagenesis kit (K1600-1; BD Biosciences, San Jose, CA) with the following primers: K4ploopFW, 5'-CCATTAGCTATGGTGACAAGACG-3'; and NheIFW, 5'-GTCAGATCCGCTATCGCTACCG-3'. G285S mutagenesis was confirmed by sequencing the $m$ KCNQ4 p-loop.

$m K C N Q 4-G 285 S$ was subcloned into the multiple cloning site pAdTrack-cmv shuttle plasmid (He et al., 1998). The resultant plasmid was linearized by digesting with restriction endonuclease Pme I, and subsequently cotransformed into BJ5183 cells with the adenoviral backbone plasmid, pAdE $\Delta$ pol (Hodges et al., 2000). Recombinants were selected for kanamycin resistance, and recombination confirmed by restriction endonuclease analyses. Finally, the linearized recombinant plasmids were transfected into $\mathrm{C} 7$ cells, an adenovirus-packaging cell line (Amalfitano et al., 1998). For large-scale production, we used serial amplification of crude cell lysate in C7 cells. After five rounds of serial passage ( $\sim 3$ weeks), the crude lysate was filtered and purified using an AdenoX viral purification kit (BD Biosciences) to yield $\sim 2 \mathrm{ml} \mathrm{Ad2-cmv-}$ mKCNQ4-G285S at a titer of $\sim 10^{9}$ viral particles $/ \mathrm{ml}$, which was aliquoted in $100 \mu \mathrm{l}$ vials and stored at $-80^{\circ} \mathrm{C}$. Ad1-ecd-hKCNQ4-G285S and Ad1-cmv-hKCNQ4-G285S were generated by Bay BioTech (Crofton, MD).

Heterologous expression of KCNQ4 in HEK293. Human embryonic kidney 293 (HEK293) cells (American Type Culture Collection, Manassas, VA) were grown in DMEM (Invitrogen, Gaithersburg, MD) supplemented with $10 \%$ FCS (Invitrogen) at $37^{\circ} \mathrm{C}$ in $5 \% \mathrm{CO}_{2}$. The day before transfection, $1 \times 10^{6}$ cells were plated in a T25 cell-culture flask (Nunc, Roskilde, Denmark). Cells were transfected with $2.5 \mathrm{mg}$ of the pAdTRACK-cmv-KCNQ4 plasmid by using Lipofectamine (Invitrogen) according to the manufacturer's instructions. Cells transfected with pAdTRACK-cmv-KCNQ4 expressed the green fluorescent protein (GFP) in the cytosol. Functional expression of KCNQ4 channels was verified by patch-clamp measurements.

Immunofluorescence. Sensory epithelia were fixed in 4\% paraformaldehyde in PBS and permeabilized with $0.1 \%$ Triton X-100. After block with 3\% normal goat serum in PBS for $1-2 \mathrm{~h}$, tissues were incubated with KCNQ4 primary antibodies (a kind gift from Dr. Bechara Kachar, National Institutes of Health-National Institute on Deafness and Other Communication Disorders, Bethesda, MD) at $4^{\circ} \mathrm{C}$ overnight. After incubation with Alexa Fluor 633 goat anti-rabbit secondary antibodies (Invitrogen) and counter staining with Alexa Fluor 546 phalloidin (Invitrogen), epithelia were mounted on coverslips using Gelmount antifade reagent (Bio-Rad) and viewed on a Zeiss (Oberkochen, Germany) 510 confocal laser-scanning microscope. Image analysis was done using Zeiss image-analysis software and Adobe (San Jose, CA) Photoshop 6.0.

Organotypic cultures. For physiology experiments, sensory epithelia were excised from postnatal P0 to P10 Swiss-Webster mice (Hilltop Labs or Taconic Farms) according to a protocol (\#3123) approved by the Animal Care Committee at the University of Virginia. Dissections were performed in MEM (Invitrogen) supplemented with $10 \mathrm{mM}$ HEPES (Sigma, St. Louis, MO) at $\mathrm{pH}$ 7.4. Cochlear coils were gently removed and isolated from the spiral ganglia. Excised turns were isolated and, after exposing the Organ of Corti, the tectorial membrane was carefully peeled away. The tissue was subsequently mounted on glass coverslips beneath a pair of thin glass fibers previously glued to the coverslip at one end. Utricles were prepared as described previously (Holt et al., 1997, 1999; Holt, 2002). To remove the otolithic membrane, epithelia were treated with protease XXIV (Sigma) added at $0.1 \mathrm{mg} / \mathrm{ml}$ for $20 \mathrm{~min}$. Utricular tissues were mounted as described for cochlear tissues. The explants were placed in culture maintained at $37^{\circ} \mathrm{C}$ in MEM (Invitrogen) supplemented with $10 \mathrm{~mm}$ HEPES, pH 7.4, $0.05 \mathrm{mg} / \mathrm{ml}$ ampicillin, and $5 \%$ bovine serum albumin. For viral transfection experiments, the vectors were applied for $4 \mathrm{~h}$ directly to culture media that lacked serum at titers that range from $1 \times 10^{8}$ to $1 \times 10^{9}$ viral particles $/ \mathrm{ml}$, as indicated in the text. Tissues were placed back in culture for $15 \mathrm{~h}$ to $10 \mathrm{~d}$ to allow for stable and robust expression of the transfected constructs. The culture media was exchanged daily.

Electrophysiology. Coverslips that contained sensory epithelia were placed in a recording chamber and bathed in standard artificial perilymph solution that contained (in mM) $144 \mathrm{NaCl}, 0.7 \mathrm{NaH}_{2} \mathrm{PO}_{4}, 5.8 \mathrm{KCl}$, $1.3 \mathrm{CaCl}_{2}, 0.9 \mathrm{MgCl}_{2}, 5.6 \mathrm{D}$-glucose, and 10 HEPES, vitamins, and amino acids (added from concentrates; Invitrogen), adjusted to $\mathrm{pH} 7.4$ and $\sim 320 \mathrm{mOsmol} / \mathrm{kg}$ with $\mathrm{NaOH}$. Hair cells were viewed from the apical surface using an upright microscope (Zeiss Axioskop FS) equipped with epifluorescence and an FITC (Chroma, Brattleboro, VT) filter set. Images were acquired using an Argus CCD camera and image processor (Hamamatsu, Bridgewater, NJ). Recording pipettes (2-4 M $\Omega$ ) were pre- 
pared from R-6 borosilicate capillary glass (Garner Glass, Claremont, CA). Pipette solutions contained (in $\mathrm{mm}$ ) $135 \mathrm{KCl}, 4 \mathrm{~K}_{4}$-EGTA, 10 HEPES, $3 \mathrm{Na}_{2} \mathrm{ATP}$, and $0.1 \mathrm{CaCl}_{2}$, adjusted to $\mathrm{pH} 7.4$ and $\sim 290$ $\mathrm{mOsmol} / \mathrm{kg}$ with $\mathrm{KOH}$. Current or voltage were recorded at room temperature $\left(22-24^{\circ} \mathrm{C}\right.$ ) using an Axopatch $200 \mathrm{~B}$ or $700 \mathrm{~A}$ (Molecular Devices), filtered at $2 \mathrm{kHz}$ with an eight-pole Bessel filter (Krohn-Hite, Brockton, MA), digitized at $>4 \mathrm{kHz}$ with a Digidata 1322A 12-bit acquisition board and pClamp 8.0 (Molecular Devices) and stored on disk for off-line analysis using Origin 7.0 (MicroCal Software). The mean series resistance was $12.5 \pm 6.8 \mathrm{M} \Omega(n=75)$ and was compensated $60-90 \%$ using the Axopatch 200B circuitry. Steady-state voltage errors caused by residual series resistance were corrected off-line. Data are presented as means \pm SEM unless otherwise noted.

Activation curves were fitted with a Boltzmann equation as follows:

$$
G\left(V_{\mathrm{m}}\right)=G_{\min }+\frac{G_{\max }-G_{\min }}{1+\exp \left({ }^{V_{1 / 2}-V_{\mathrm{m}}}\right)} .
$$

$G_{\max }$ and $G_{\min }$ are the maximum and minimum conductances, respectively. $\mathrm{V}_{(1 / 2)}$ is the midpoint of the curve at which half of the conductance is activated, and $s$ is the slope of the curve at the midpoint.

\section{Results}

\section{Expression of KCNQ4 mRNA in the mouse utricle}

To identify the temporal pattern of expression of KCNQ4 in the developing mouse utricle, we used quantitative RT-PCR to examine mRNA extracted from the sensory epithelia of utricles excised from mice that ranged in age from E15 to P9 (Fig. $1 A$ ). We noted a sharp rise KCNQ4 expression levels at E17-E18, which was positively correlated with the onset of $G_{\mathrm{K}, \mathrm{L}}$ expression that we characterized previously (Géléoc et al., 2004). Previously, Rocha-Sanchez et al. (2007) also noted the onset of KCNQ4 immunolocalization in E18 hair cells of the developing mouse utricle. At early postnatal stages, there was a decline in the level of KCNQ4 mRNA present in utricle sensory epithelia despite the persistence of the KCNQ4 immunoreactivity (Rocha-Sanchez et al., 2007) and the physiological expression of $G_{\mathrm{K}, \mathrm{L}}$. As a possible interpretation of this mRNA expression pattern, we propose that at the onset of KCNQ4 expression, $\sim \mathrm{E} 18$, a large rise in protein synthesis is required. As protein levels reach steady state, mRNA levels drop to a maintenance level of expression. Similar expression patterns have been noted for KCNQ4 (Beisel et al., 2005) and prestin (Judice et al., 2002; Zheng et al., 2002) in cochlear hair cells, which suggests that the turnover rate may be slower for some hair-cell proteins than the corresponding mRNA turnover rate.

Four alternative splice variants of KCNQ4 have been identified previously in tissue harvested from mouse cochleas and vestibular organs (Beisel et al., 2005; Rocha-Sanchez et al., 2007). Three splice forms result from the alternate use of exons 9 through 11, and the fourth lacks all three exons. To examine the expression of the various splice forms in mouse utricle, we used conventional RT-PCR and designed primer sets that spanned exons 8 through 12 . The amplification products were sequenced to establish their identity. We confirmed splice variant KCNQ4_V1, which includes exon 10, as the predominant form expressed at E18, P5, and P10, but also noted transient expression of splice form $K C N Q \_V 3$ at P5, which uses exon 9 (Fig. $1 B$ ). We could not rule out expression of other splice forms at levels that were below our detection limit.

Previous immunolocalization revealed that KCNQ4 subunits are expressed in hair cells and perhaps vestibular ganglion neurons as well (Kharkovets et al., 2000; Rocha-Sanchez et al., 2007). Because the tissue we harvested for these experiments contained only the sensory epithelium, which included hair cells, support-

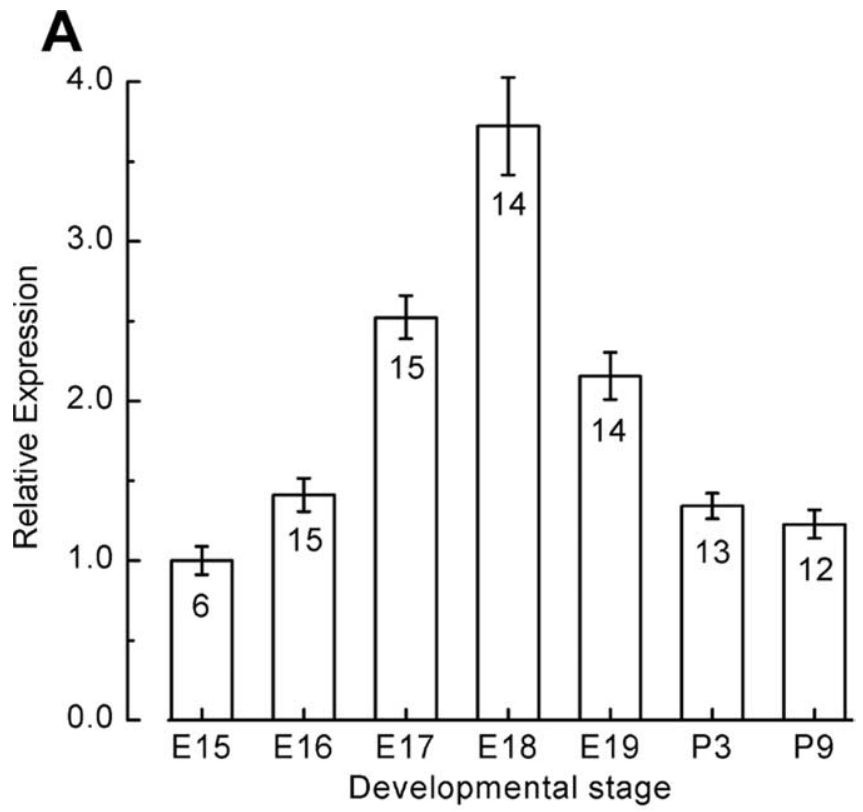

B

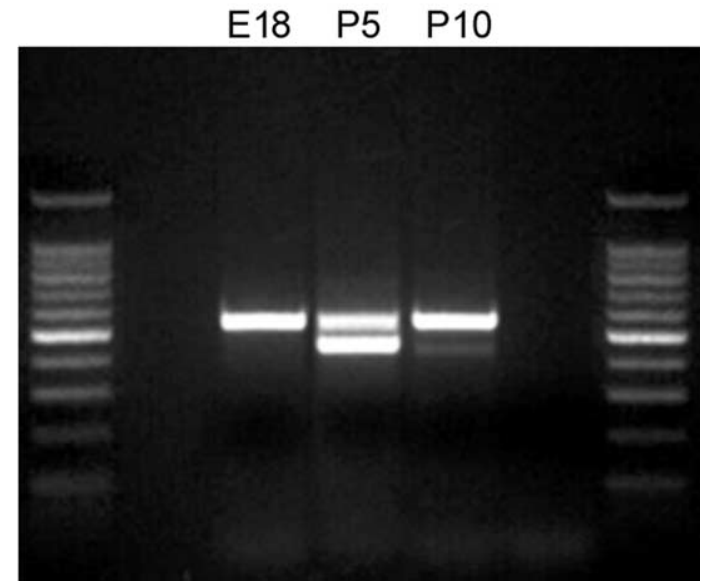

Figure 1. Expression of KCNQ4 mRNA in the mouse utricle. $A$, Quantitative real-time RT-PCR was used to examine the expression pattern of KCNQ4 in the developing mouse utricle. A standard curve was generated using tenfold dilution series of plasmid DNA that carried the coding sequence for $m K C N Q 4$ was used to confirm primer efficiency. The relative expression levels are plotted as a function of developmental stage. The number of samples and SEs are shown for each stage. $\boldsymbol{B}$, Image of an agarose gel electrophoresis showing the amplification products of an RT-PCR using primers that span exons 8 through 12 of $m K C N Q 4$ and template harvested from the developmental stages indicated. A 1 kb ladder was run in lanes 1 and 5. Bands of 528 and 423 base pairs were amplified at P5 and P10.

ing cells, and the nerve terminals of the afferents and efferents but not their cell bodies, we conclude that the most likely source of the template mRNA was the hair cells themselves.

\section{Generation of viral vectors}

To identify the electrophysiological correlate of KCNQ4 expression in hair cells, we began by generating adenoviral vectors that carried the coding sequence for a mutant form of either human KCNQ4 ( $h K C N Q 4)$ or mouse KCNQ4 ( $m$ KCNQ4). We used sitedirected mutagenesis to generate an $A$ to $G$ point mutation in $m K C N Q 4$, which resulted in an amino acid substitution at position 285 from a glycine to a serine, referred to as G285S. Three adenoviral vectors were generated: two that carried the coding sequence for $h K C N Q 4-G 285 S$ and one that carried the coding sequence for $m K C N Q 4-G 285 S$. The hKCNQ4 sequences were 
A

Ad1-cmv-hKCNQ4-G285S = CMV $=$ GFP IRES hKCNQ4-G285S = Ad1-ecd-hKCNQ4-G285S EECD=GFP IRES hKCNQ4-G285S= Ad2-cmv-mKCNQ4-G285S = CMV GFP CMV - mKCNQ4-G285S
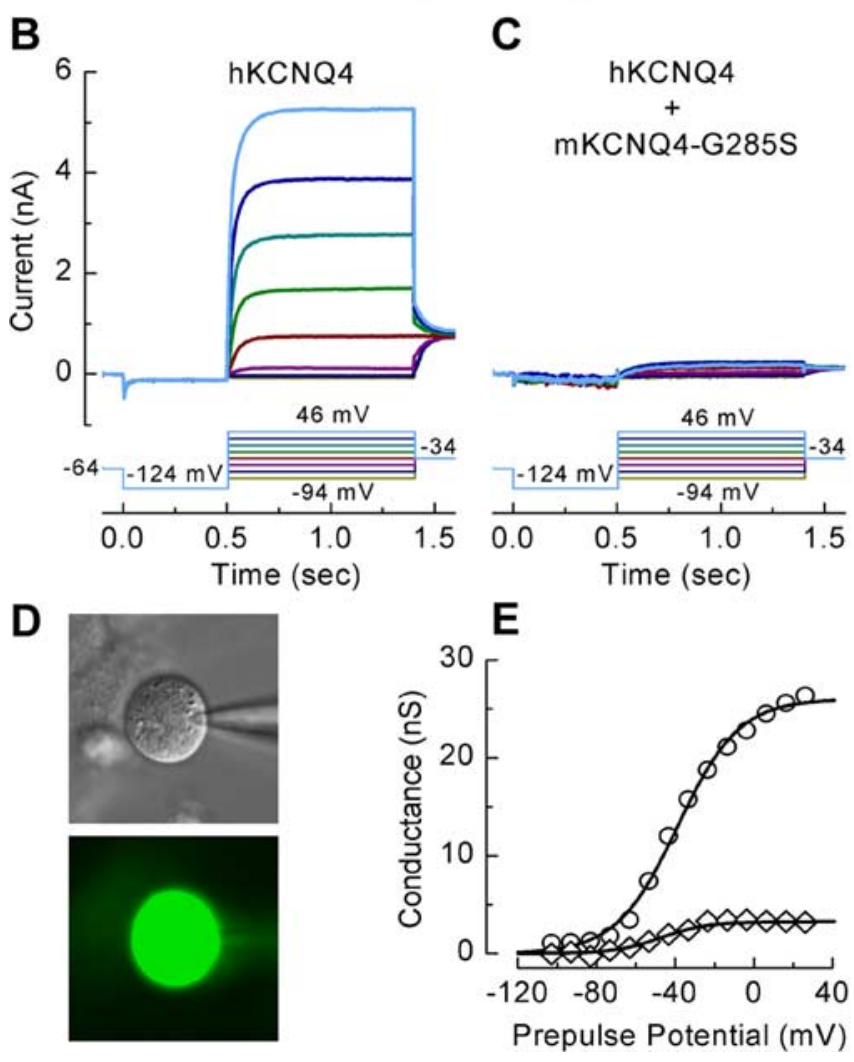

Figure 2. Generation and validation of adenoviral expression of mutant KCNQ4. A, Vector maps of the expression cassette introduced into the three adenoviral vectors used for this study. Promoter sequences are shown in blue, GFP in green, and the coding sequence of KCNQ4 in yellow. The name assigned to each vector is shown at the left. $\boldsymbol{B}, \mathrm{A}$ family of currents recorded from HEK293 cells stably transfected with hKNCQ4 (Sogaard et al., 2001). The voltage protocol is shown below. C, The stably transfected cells were exposed to $1 \times 10^{5}$ viral particles $/ \mathrm{ml}$ of A2-mKCNQ4-G285S for $4 \mathrm{~h}$. Twenty-four hours later, GFP-positive cells were identified. Shown is a representative family of currents evoked by the protocol shown below. D, DIC and fluorescence images from an A2-mKCNQ4-G285S-transfected HEK293 cell. E, Activation curves derived from the data shown in $\boldsymbol{B}$ and $\boldsymbol{C}$. The wild-type hKNCQ4 (circles) and mutant mKCNQ4-G285S (diamonds) were fit with Boltzmann curves that had the following parameters, respectively: $G_{\max } 25.8 \mathrm{nS} ; V_{(1 / 2)},-34 \mathrm{mV} ; s, 18.6 \mathrm{mV} ; G_{\max }, 3.2 \mathrm{nS} ; V_{(1 / 2)},-43 \mathrm{mV} ; s, 11.9 \mathrm{mV}$.

packaged into E1a/b-deleted adenoviral vectors that were replication incompetent and the $m K C N Q 4$ sequence was packaged into multiply deleted adenoviral vectors that lacked E1a/b, E3, pol, and pTP as described previously (Amalfitano et al. 1998; Hodges et al., 2000). Expression of $h K C N Q 4$ was driven by either the constitutively active $\mathrm{cmv}$ promoter or an inducible ecdysone promoter (Holt et al., 1999; Johns et al., 1999). All three vectors also contained the coding sequence for GFP as a transfection marker whose expression was driven either by a separate $\mathrm{cmv}$ promoter or via an internal ribosomal entry sequence (IRES). Vector maps for the three constructs are shown in Figure $2 \mathrm{~A}$.

To confirm that the viral vectors we generated expressed both the KCNQ4 construct and GFP, we transfected an HEK293 cell line that was already stably transfected with wild-type hKNCQ4
(Sogaard et al., 2001). We exposed the cells to $\times 10^{5}$ viral particles/ml of A2-mKCNQ4-G285S for $4 \mathrm{~h}$. We also sought to confirm that the G285S mutation evoked dominant-negative suppression of wild-type KCNQ4 function and we recorded wholecell currents from both GFP-negative, which expressed wild-type hKNCQ4, and GFP-positive HEK cells 24 h after viral transfection. Invariably, we found that the stably transfected GFPnegative cells expressed large outward potassium currents (Fig. $2 B$ ) as described previously (Sogaard et al., 2001), but that GFPpositive cells, which presumably coexpressed both the wild-type and mutant forms of KCNQ4, lacked those currents almost entirely (Fig. 2C). In most cases, the currents recorded from GFPpositive cells were similar to currents recorded from nontransfected, control HEK cells (data not shown). Based on these data, we conclude that our adenoviral vectors were able to drive functional expression of mutant KCNQ4 and that the virally expressed G285S mutant subunits were able coassemble with the wild-type subunits to exert dominant-negative suppression of the endogenous channels. We also note that mouse and human KCNQ4 subunits were able to coassemble because suppression of wild-type hKCNQ4 currents by mKCNQ4-G285S was robust and reproducible.

In Figure $2 E$, we plot the activation curves from the data shown in Figure 2, $B$ and $C$. The data were fit with a Boltzmann equation, which revealed a voltage of half-maximal activation $\left(V_{(1 / 2)}\right)$ of $-34 \mathrm{mV}$ and slope of $18.6 \mathrm{mV}$ in the GFP-negative cells. HEK cells transiently transfected with wild-type mKCNQ4 showed similar properties of voltage-dependent activation (data not shown). Our electrophysiological data recorded from heterologous cells that express hKCNQ4 are consistent with previous reports (Kubisch et al., 1999; Sogaard et al., 2001; Chambard and Ashmore, 2005), which again draws attention to a puzzling discrepancy. Despite the credible evidence that supports KCNQ4 expression in both auditory and vestibular hair cells, none of the properties of the potassium conductances expressed in hair cells match the properties of KCNQ4 expressed in heterologous cells. This discrepancy has confounded identification of the physiological correlate of KCNQ4 expression.

\section{Molecular expression of KCNQ4 in utricle hair cells}

To identify the hair-cell potassium conductances carried by KCNQ4, we infected hair cells of the mouse utricle in vitro. Organotypic explants were generated between P5 and P7 and maintained in culture for $12-72 \mathrm{~h}$ bathed in OptiMEM supplemented with ampicillin and HEPES. Viral vectors were added directly to the culture media for 4-24 h. In the first series of experiments, we used an inducible expression system, which required that we cotransfect with two vectors, Ad1-VgRXR (Holt et al., 1999; Johns et al., 1999) and Ad1-ecd-hKCNQ4-G285S. Application of $4 \mu \mathrm{M}$ Muristerone A, an ecdysone analog, was used to activate the ecdysone promoter and induce expression of hKCNQ4-285S and GFP. Our initial aim was to confirm hair-cell transfection and expression of the exogenous proteins. Forty-eight hours after transfection, we fixed the tissue stained with an antibody directed against the c terminus of KCNQ4 (Kharkovets et al., 2000) and counterstained with phalloidin-Alexa546 to illuminate the actinrich hair bundles. Figure $3 A$ shows the apical surface of $\sim 60 \%$ of the epithelium, which includes the central region, and Figure $3 B$ shows the GFP-positive cells in the same field focused at the cell-body level. Because the GFP signal reflects the number of cells that were successfully transfected, we counted GFP-positive cells to estimate the transfection rate. The mature mouse utricle contains $\sim 3000$ hair cells (Desai et al., 2005). Assuming a uni- 

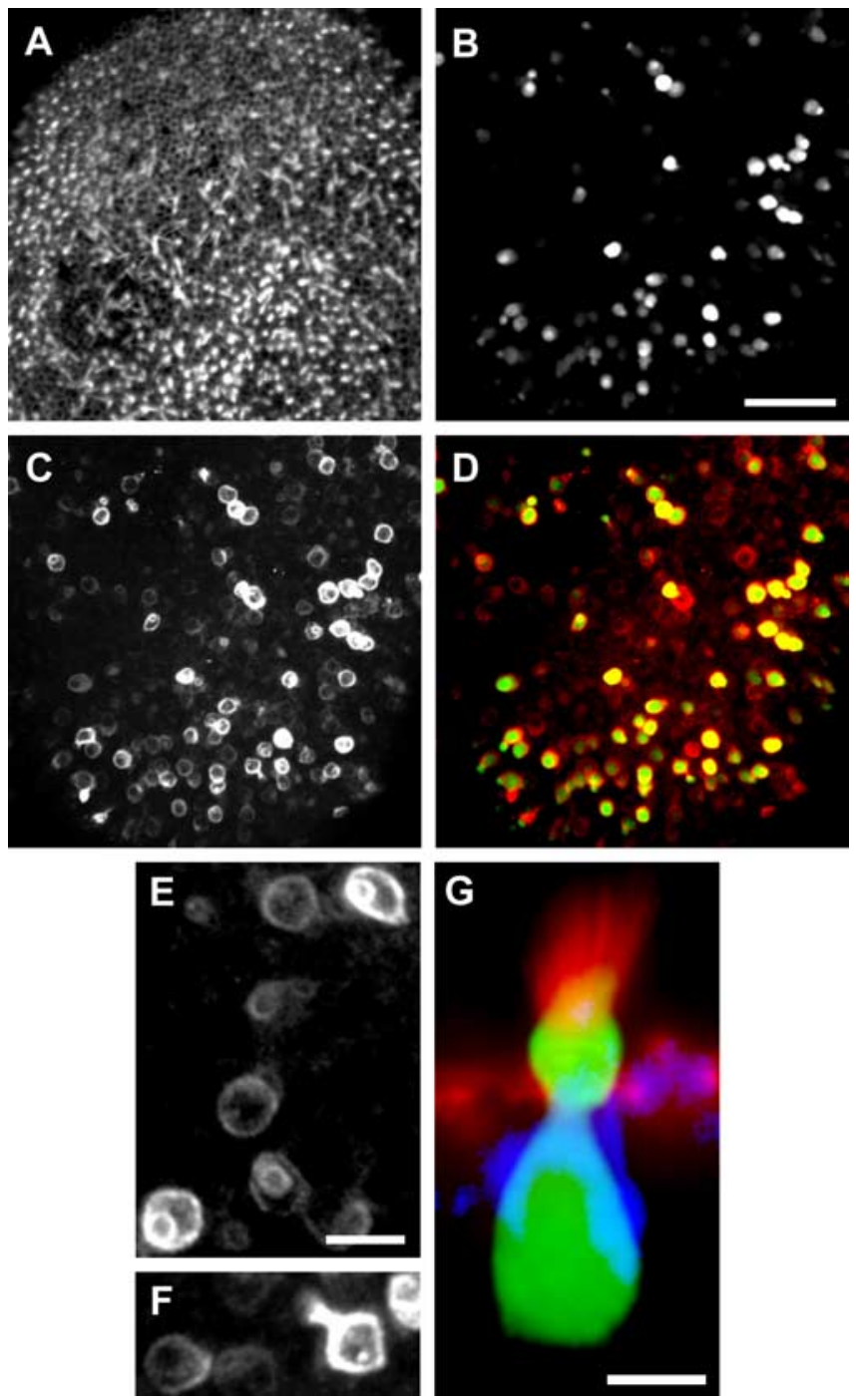

Figure 3. Confocal images of a P8 mouse utricle explant $48 \mathrm{~h}$ after transfection with $8.6 \times$ $10^{8}$ particles $/ \mathrm{ml}$ of Ad1-VgRXR and $1.4 \times 10^{10}$ particles $/ \mathrm{ml}$ of Ad1-ecd-hKCNQ4-G285S. $A$, Top-down view of the whole-mount utricle with the actin-rich hair bundles illuminated with phalloidin-Alexa546. A $z$-series that consisted of 20 focal planes was collapsed to generate images $\boldsymbol{A}-\boldsymbol{F}$. $\boldsymbol{B}$, The GFP signal from the same field as shown in $\boldsymbol{A}$. $\boldsymbol{C}$, The same field as shown in $\boldsymbol{A}$ and $\boldsymbol{B}$ stained with anti-KCNQ4 and an Alexa633 secondary antibody. $\boldsymbol{D}$, Merge of $\boldsymbol{B}$ and $\boldsymbol{C}$ with GFP shown in green and KCNQ4 shown in red. $\boldsymbol{E}$, Close-up view of several KCNQ4-postive cells. The cells in the top right and lower left were also positive for GFP. Note the ring within a ring pattern of fluorescence that characterized both the transfected type I cells and the nontransfected type I cells (bottom center). $\boldsymbol{F}$, Close-up view of a GFP-positive type I cell (right) that reveals the restricted neck region. $\mathbf{G}$, High-magnification cross-sectional view of a GFP-positive type I cell with GFP in green, phalloidin in red, and KNCQ4 in blue. Scale bars: (in $B) A-D, 50 \mu \mathrm{m}$; $E, F, 10 \mu \mathrm{m} . G, 5 \mu \mathrm{m}$.

form density, we estimate that the images contain 1800 hair cells, 74 of which were GFP positive. Thus, the transfection rate for this experiment was $\sim 4.1 \%$.

Figure $3 C$ shows the pattern of KNCQ4 immunoreactivity. After $48 \mathrm{~h}$ in culture, the afferent and efferent nerve terminals had decayed; thus, we attributed the immunoreactivity visible in Figure $3 C$ to the living cells retained at the time of fixation. The KCNQ4 antibody was cross-reactive with both mouse and human KCNQ4, which prevented us from distinguishing the endogenous wild-type mKCNQ4 expression from expression of exogenous mutant hKCNQ4. A merge of the GFP and KCNQ4 signals is shown in Figure $3 D$. Note that there were many
KCNQ4-positive cells that were not GFP-positive, which presumably reflected expression of endogenous mKCNQ4. All the GFP-positive cells were also positive for KCNQ4. Because we never saw GFP-positive cells that lacked a KCNQ4 signal, we assume that those cells expressed exogenous hKCNQ4 and perhaps endogenous mKCNQ4 as well. The alternative hypothesis that the tropism of the viral vector was specific for mKCNQ4positive cells seems less likely because we have shown previously that adenovirus can infect both type I and type II cells (Holt, 2002) and have shown that utricle hair cells can be infected as early as E15 (Corey et al., 2004), well before KCNQ4 immunoreactivity appears (Rocha-Sanchez et al., 2007). Furthermore, we often noted greater intensity in KCNQ4 immunostaining in GFP-positive cells relative to GFP-negative cells, suggesting a contribution from both endogenous and exogenous protein.

Desai et al. (2005) reported that $\sim 55 \%$ of the hair cells in the mouse utricle are type I cells. Whereas we found it difficult to rule out the presence of immunoreactivity in type II cells, numerous type I cells were positive for KCNQ4, including both GFPnegative and GFP-positive cells. The restricted neck region that typifies the flask-shaped morphology of the type I cells was particularly evident when confocal images were acquired a multiple focal planes ( $z$-series). Figure $3 E$ shows a collapsed $z$-series that revealed the neck region and the more bulbous cell body as a circle within a circle for two GFP-positive cells (top right and bottom left) and a single GFP-negative cell (bottom center). Figure $3 F$ shows another collapsed $z$-series example of a GFPpositive type I cell, but in this case the cell is oriented orthogonal to the image plane. Figure $3 G$ shows a triple label, high magnification, cross-sectional view of a single image plane that reveals a GFP- and KCNQ4-positive type I hair cell.

\section{Potassium currents expressed in utricle hair cells}

Consistent with previous reports, we found that type I and type II hair cells from P8 mouse utricles expressed large outwardly rectifying $\mathrm{K}^{+}$currents (Rüsch et al., 1998). We used the whole-cell configuration of the tight-seal recording technique in voltageclamp mode to record from single cells in the central region of the intact sensory epithelium. Flask-shaped type I cells and cylindrical type II hair cells were easily distinguished by focusing through epithelia mounted in the recording chamber and visualized with a $63 \times$ objective and differential interference contrast (DIC) optics. Our standard voltage protocol consisted of a step from the holding potential of $-64 \mathrm{mV}$ to $-124 \mathrm{mV}$ for $100 \mathrm{~ms}$ followed by a family of voltage steps that ranged between -104 and $16 \mathrm{mV}$. At the termination of each step in the family, we stepped back to $-34 \mathrm{mV}$.

A representative family of currents recorded from a type II hair cell is shown in Figure $4 A$. In type II cells there was little holding current at $-64 \mathrm{mV}$ and very little inward current at -124 $\mathrm{mV}$. Steps positive to $-44 \mathrm{mV}$ evoked time- and voltagedependent activation of outward potassium currents with kinetics similar to those described previously (Rüsch et al., 1998). Rüsch et al. (1998) termed the conductance that carried the currents $G_{\mathrm{DRII}}$ for delayed rectifier, type II. To quantify the activation range of $G_{\mathrm{DRII}}$ in our experiments, we measured the tail current at the moment of the step to $-34 \mathrm{mV}$, converted to conductance and plotted it as a function of prepulse potential (Fig. 4C, circles). The data were fitted with a Boltzmann equation (line), which revealed a $V_{(1 / 2)}$ of $-44 \mathrm{mV}$, a steepness of $6.7 \mathrm{mV}$, and a maximum conductance of $23 \mathrm{nS}$, which was consistent with $G_{\text {DRII }}$, but in sharp contrast to the prominent conductance of type I hair cells. Using a similar voltage protocol, we recorded from type I 

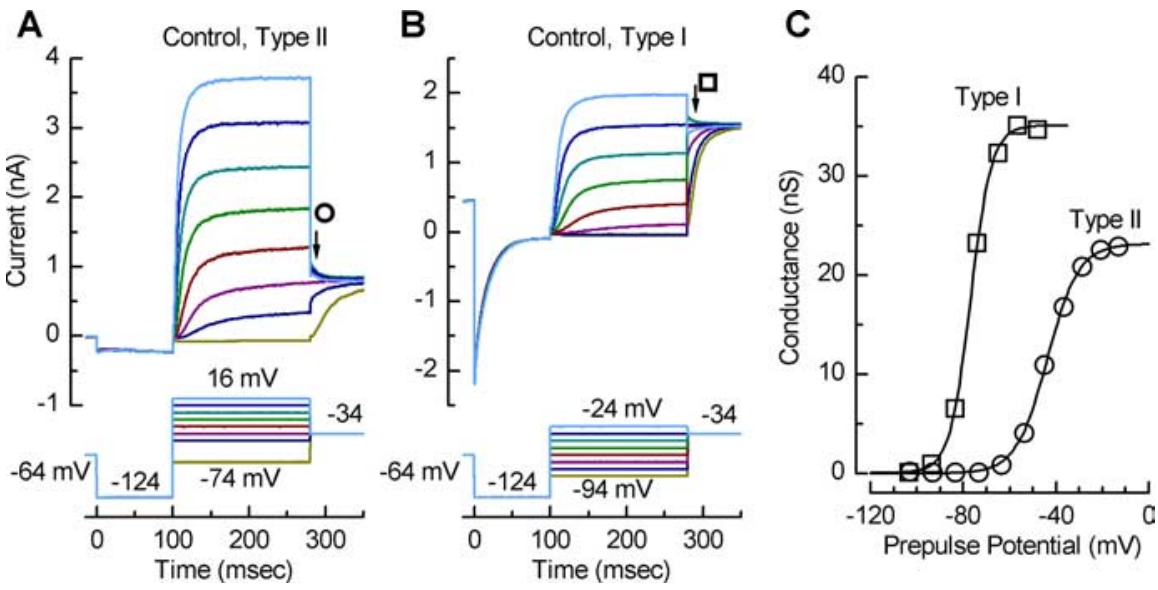

Figure 4. Representative control potassium currents recorded from nontransfected vestibular hair cells. $A, A$ family of control currents recorded from nontransfected type II cell at P7. The voltage protocol is shown below. $B, A$ family of control currents recorded from nontransfected type I cell at P6. C, Activation curves for the type II (circles) and type I cells (squares) shown in $A$ and $\boldsymbol{B}$. The tail currents at the moment of the step to $-34 \mathrm{mV}$ was sampled, divided by driving force $(37 \mathrm{mV})$ to convert to conductance, and plotted verses the iterated step potentials. The data were fit with Boltzmann relations with the following parameters: type II, $V_{(1 / 2),}-44 \mathrm{mV} ; s, 6.7 \mathrm{mV} ; G_{\max }, 23 \mathrm{nS} ;$ type I, $V_{(1 / 2)},-77 \mathrm{mV} ; s, 4.4 \mathrm{mV} ; G_{\max }, 35 \mathrm{nS}$.

A

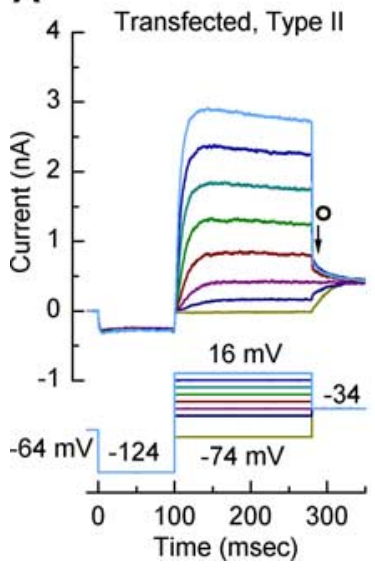

B

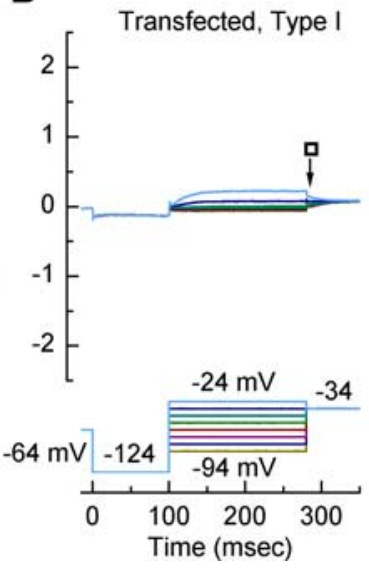

C

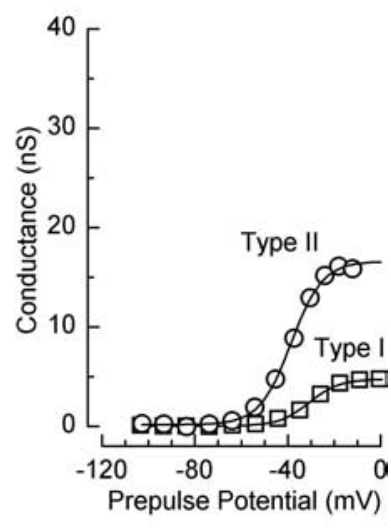

Figure 5. Representative currents recorded from GFP-positive hair cells exposed to $4.3 \times 10^{8}$ particles $/ \mathrm{ml}$ of $\mathrm{Ad1}$ - $\mathrm{VgRXR}$ and $7 \times 10^{9}$ particles/ml of Ad1-ecd-hKCNQ4-G285S. $\boldsymbol{A}, \mathrm{A}$ family of currents recorded from a type II hair cell excised at P4 and maintained in culture for $4 \mathrm{~d}$. $B, A$ family of currents recorded from a type I hair cell excised at $P 7$ and maintained in culture for $2 \mathrm{~d}$. $\boldsymbol{C}$, Activation curves generated from the data shown in $\boldsymbol{A}$ and $\boldsymbol{B}$ and fitted with Boltzmann relations that had the following fit parameters: type II (circles), $V_{(1 / 2)},-39 \mathrm{mV} ; \mathrm{s}, 6.8 \mathrm{mV} ; G_{\text {max }}, 17 \mathrm{nS}$; type I (squares), $V_{(1 / 2)},-31 \mathrm{mV} ; s, 6.5 \mathrm{mV} ; G_{\max }, 4.8 \mathrm{nS}$.

hair cells in the same epithelium and observed a strikingly different current profile (Fig. 4 B). At the holding potential of $-64 \mathrm{mV}$, we often noted a standing outward current that, in some cases, was as large as $1 \mathrm{nA}$. Furthermore, hyperpolarization to $-124 \mathrm{mV}$ resulted in large instantaneous inward currents, which decayed toward baseline in the subsequent $100 \mathrm{~ms}$. We attributed the holding current and the large inward current to channels that were open at the holding potential and deactivated with hyperpolarization. Depolarizing voltage steps reactivated the channels to yield the family of outward currents shown in Figure $4 B$. The properties of these currents were consistent with those described previously for mouse type I hair cells (Rüsch and Eatock, 1996; Rüsch et al., 1998; Chen and Eatock, 2000). To examine the activation of the conductance, we used the same method described for type II cells and fitted the data with a Boltzmann curve that had a $V_{(1 / 2)}$ of $-77 \mathrm{mV}$, a steepness of $4.4 \mathrm{mV}$, and a maximum conductance of $35 \mathrm{nS}$, again similar to the conductance Rüsch and Eatock (1996) called $G_{\mathrm{K}, \mathrm{L}}$, for lowvoltage-activated $\mathrm{K}^{+}$conductance.

Dominant-negative suppression of $G_{K, L}$ in type I cells

To identify whether KCNQ4 subunits contributed to the formation of $G_{\mathrm{DRII}}$ or $G_{\mathrm{K}, \mathrm{L}}$, we exposed organotypic cultures generated from mouse utricle epithelia excised between P5 and P7 to either Ad1ecd-hKCNQ4-G285S or Ad2-cmvmKNCQ4-G285S for $4 \mathrm{~h}$ and recorded from GFP-positive type II and type I cells 24-72 h posttransfection. The family of currents shown in Figure $5 A$ was recorded from a representative GFP-positive type II hair cell $48 \mathrm{~h}$ postinfection with Ad1-ecdhKCNQ4-G285S. Although there was a slight reduction in the amplitude of the currents relative to the uninfected control type II currents (Fig. $4 A$ ), other properties were quite similar, including the activation and deactivation kinetics and the voltage range of activation. The effect in type I cells, however, was quite dramatic. Figure $5 B$ shows a representative family of currents from a GFP-positive type I cell recorded $24 \mathrm{~h}$ after transfection. The current profile lacked the outward holding current at the holding potential of $-64 \mathrm{mV}$, the large instantaneous inward current at the step to $-124 \mathrm{mV}$, the subsequent deactivation, and the large outward currents activated by depolarization, all of which typify uninfected, control type I hair cells (Fig. $4 B)$. The tail currents at the moment of the step to $-34 \mathrm{mV}$ from both the GFPpositive type I (squares) and type II (circles) cells were plotted as a function of prepulse potential and fitted with Boltzmann relations (Fig. 5C). The fit parameters for the GFP-positive type II cell were similar to those of the GFP-negative type II cell: $V_{(1 / 2)}$ of $-39 \mathrm{mV}$, a steepness of $6.8 \mathrm{mV}$, and a $G_{\max }$ of $17 \mathrm{nS}$. The activation curve for the GFP-positive type I cell was markedly different from the GFP-negative type I cell, but had Boltzmann parameters somewhat similar to those of the type II cells: $V_{(1 / 2)}$ of $-31 \mathrm{mV}$, a steepness of $6.5 \mathrm{mV}$, and a $G_{\max }$ of $4.8 \mathrm{nS}$. The lack of a negatively activated conductance as evidenced by the more positive $V_{(1 / 2)}$ suggested that $G_{\mathrm{K}, \mathrm{L}}$ was strongly suppressed in the GFP-positive type I cell. The small conductance that remained in those cells resembled $G_{\mathrm{DRII}}$, which is the predominant outward $\mathrm{K}^{+}$conductance in the type II cells. Furthermore, the lack of suppression of $G_{\text {DRII }}$ in the type II and type I cell was evident from the similar current profiles and activation curves in those cells. We obtained similar results when recording from GFP-positive type I and type II cells infected with Ad2-cmvmKNCQ4-G285S, suggesting that both hKNCQ4-G285S and mKNCQ4-G285S were capable of suppressing $G_{\mathrm{K}, \mathrm{L}}$. Images of an Ad2-cmv-mKNCQ4-G285S transfected epithelium are shown in supplemental Figure 1 (available at www.jneurosci.org as supplemental material). 
A

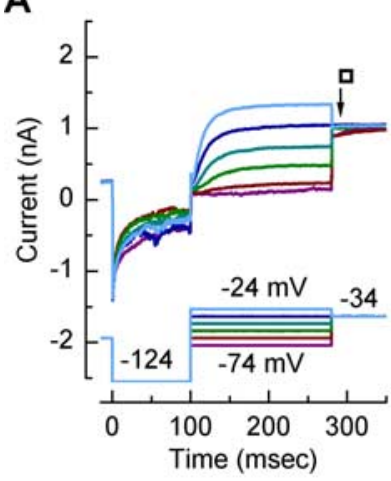

B

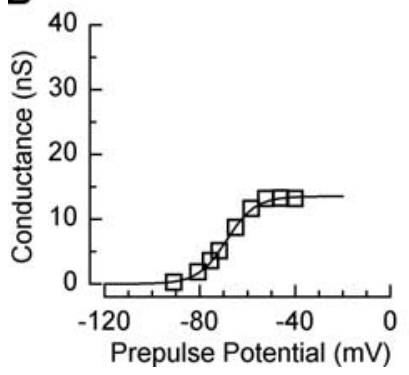

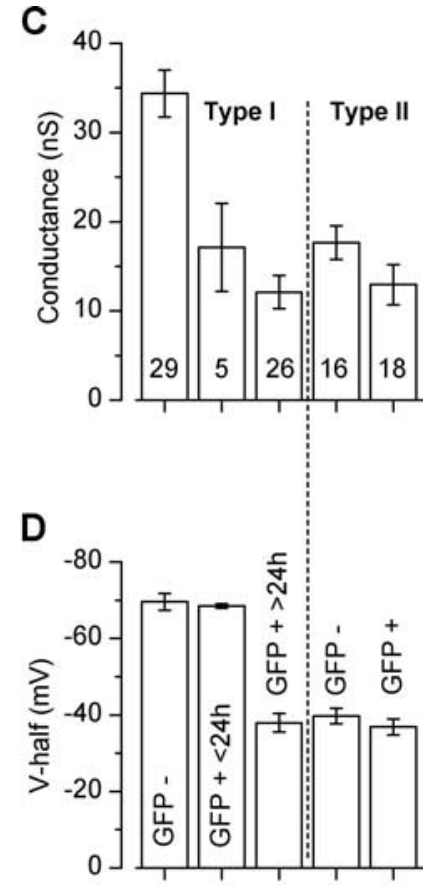

Figure 6. Summary of dominant-negative inhibition of the potassium currents in vestibular hair cells. $A$, A family of currents recorded from a type I cell excised at P7. The epithelium was exposed to $4.3 \times 10^{8}$ particles $/ \mathrm{ml}$ of Ad1-VgRXR and $7 \times 10^{9}$ particles $/ \mathrm{ml}$ of Ad1-ecdhKCNQ4-G285S and cultured for $18 \mathrm{~h}$. Note the partial reduction in current amplitude. $\boldsymbol{B}$, Activation curve generated from the tail currents shown in $\boldsymbol{A}$. The data were fit with a Boltzmann equation that had a $V_{(1 / 2)}$ of $-69 \mathrm{mV}$, a steepness of $6.1 \mathrm{mV}$, and a $G_{\max }$ of $14 \mathrm{nS}$, which indicated partial suppression of $G_{K, L} \cdot C$, The bar graph summarizes mean whole-cell conductance data taken from the $G_{\max }$ of Boltzmann fits to 94 activation curves. The number of cells analyzed for each group is indicated at the bottom of each bar. Error bars represent SEM. The bar labels in $\boldsymbol{D}$ also apply to $\boldsymbol{C}$. $\boldsymbol{D}$, Summary of the mean $V_{(1 / 2)}$ data for the Boltzmann fits to the 94 activation curves shown in $C$.

Interestingly, at intermediate times after exposure to either viral vector we noted intermediate levels of $G_{\mathrm{K}, \mathrm{L}}$ suppression (Fig. $6 A)$. Fifteen to $20 \mathrm{~h}$ after infection, evidence of $G_{\mathrm{K}, \mathrm{L}}$ expression remained albeit with a diminished amplitude. Figure $6 B$ shows the activation curve generated from the representative data shown in Figure $6 \mathrm{~A}$. The data were fitted with a Boltzmann curve that had a $V_{(1 / 2)}$ of $-69 \mathrm{mV}$, a steepness of $6.1 \mathrm{mV}$, and a $G_{\max }$ of $14 \mathrm{nS}$.

In total, we recorded from 94 cells. The data from Boltzmann fits to the activation curves are summarized in Figure 6, $C$ and $D$. There was a significant $\left(p<10^{-7}\right)$ reduction in the mean amplitude of the whole-cell conductance in the GFP-positive type I cells relative to the GFP-negative type I cells. To the contrary, there was a small but statistically insignificant $(p>0.1)$ difference between the mean amplitudes of the whole-cell conductance in the GFP-negative and -positive type II cells. Similarly, $V_{(1 / 2)}$ of activation was significantly different $\left(p<10^{-12}\right)$ between the GFP-positive and -negative type I cells, but was very similar $(p>$ 0.1 ) between the two populations of type II cells. For the five GFP-positive type I cells that we recorded from 15 to $20 \mathrm{~h}$ post infection, we noted a significant $(p<0.05)$ reduction in the amplitude of the currents (Fig. 6C), but no significant $(p>0.5)$ difference in the $V_{(1 / 2)}$ of activation (Fig. $6 D$ ), which suggested that $G_{\mathrm{K}, \mathrm{L}}$ was suppressed, but not entirely.

Together, these data indicate that exogenous expression of either hKNCQ4-G285S or mKNCQ4-G285S can induce dominant-negative suppression $G_{\mathrm{K}, \mathrm{L}}$ in type I hair cells in the central region of the P6-P12 mouse utricle. Therefore, we conclude that $G_{\mathrm{K}, \mathrm{L}}$ is most likely composed of homomeric KCNQ4 channels and/or heteromeric channels that can include KCNQ4 and its coassembly partners.

\section{Molecular expression of KCNQ4 in cochlear hair cells}

Previous reports have suggested that the low-voltage activated potassium conductance, termed $G_{\mathrm{K}, \mathrm{n}}$, first identified in guinea pig outer hair cells (Housley and Ashmore, 1992), consists of KCNQ4 subunits (Holt and Corey, 1999; Marcotti and Kros, 1999; Trussell, 2000; Kharkovets et al., 2000, 2006). Furthermore, Beisel et al. (2000, 2005) have noted a temporal correlation between the physiological expression of $G_{\mathrm{K}, \mathrm{n}}$ and the molecular expression of KCNQ4, both following an apical to basal expression pattern. Previously, Kharkovets et al. (2006) also showed a lack of $G_{K, n}$ expression in KCNQ4 knock-out mice. To verify the link between $G_{K, n}$ and KCNQ4 and the effectiveness of our dominant-negative adenoviral vector approach, we generated cochlear explants cultures and applied Ad1-cmv-hKCNQ4-G285S directly to the culture media.

We began by excising mouse cochleae at P0, $8 \mathrm{~d}$ before the onset of $G_{\mathrm{K}, \mathrm{n}}$ (Marcotti and Kros, 1999) and endogenous KCNQ4 expression (Beisel et al., 2005). To confirm transfection and expression of GFP and hKCNQ4-G285S, we applied Ad1-cmvhKCNQ4-G285S with a titer of $5 \times 10^{9}$ viral particles/ml for $4 \mathrm{~h}$. Two days later, the tissue was fixed and stained with an antiKCNQ4 antibody and phalloidin (Fig. 7). Of the 27 outer hair cells apparent in this field, 23 were GFP-positive, indicating a transfection rate of $85 \%$. Of the 23 GFP-positive cells, 20 were also positive for KCNQ4. The slightly lower rate of KCNQ4 expression is not surprising given the bicistronic design of the viral construct which consisted of a single cmv promoter, the coding sequence for GFP followed by an IRES and $h K C N Q 4-G 285 S$. In bicistronic expression systems, the gene that is downstream of the IRES is often expressed at lower levels, in this case, perhaps below the detection limit of our antibody. Nonetheless, $87 \%$ of the cells that were GFP-positive were also positive for KCNQ4 at the equivalent of P3, $\sim 5 \mathrm{~d}$ before the onset of endogenous KCNQ expression, which raised confidence that the vector could drive expression of exogenous hKCNQ4-G285S in a high percentage of outer hair cells: $\sim 74 \%$. Inner hair cells were infected as well, albeit at a lower rate, but because they have lower expression levels of endogenous KCNQ4 and $G_{K, n}$ (Oliver et al., 2003) they were not the focus of this study.

\section{Dominant-negative suppression of $G_{K, n}$ in outer hair cells}

When we applied the same voltage protocol used to characterize the potassium currents of vestibular hair cells we recorded the currents shown in Figure $8 \mathrm{~A}$ from an outer hair cell from the apical end of the cochlea. Although there were a few differences (Wong et al., 2004), many of the general features of the whole-cell currents we recorded in cochlear outer hair cells were similar to those of the type I vestibular cells, including the standing outward current at the holding potential of $-64 \mathrm{mV}$, deactivation of the inward current at $-124 \mathrm{mV}$, and reactivation of the current after depolarization. The tail currents measured at the moment of the step to -34 were plotted as a function of prepulse potential (Fig. $8 C$, squares) and revealed a broad activation range, which we fit with two Boltzmann relations. The first had the negative activation range and fit parameters consistent with those of $G_{K, n}$ as described previously (Housley and Ashmore, 1992): a $V_{(1 / 2)}$ of $-77 \mathrm{mV}$, a steepness of $7.4 \mathrm{mV}$, and a $G_{\max }$ of $7.4 \mathrm{nS}$. The second activated more positively, consistent with $G_{\mathrm{K}}$ : a $V_{(1 / 2)}$ of $-25 \mathrm{mV}$, 

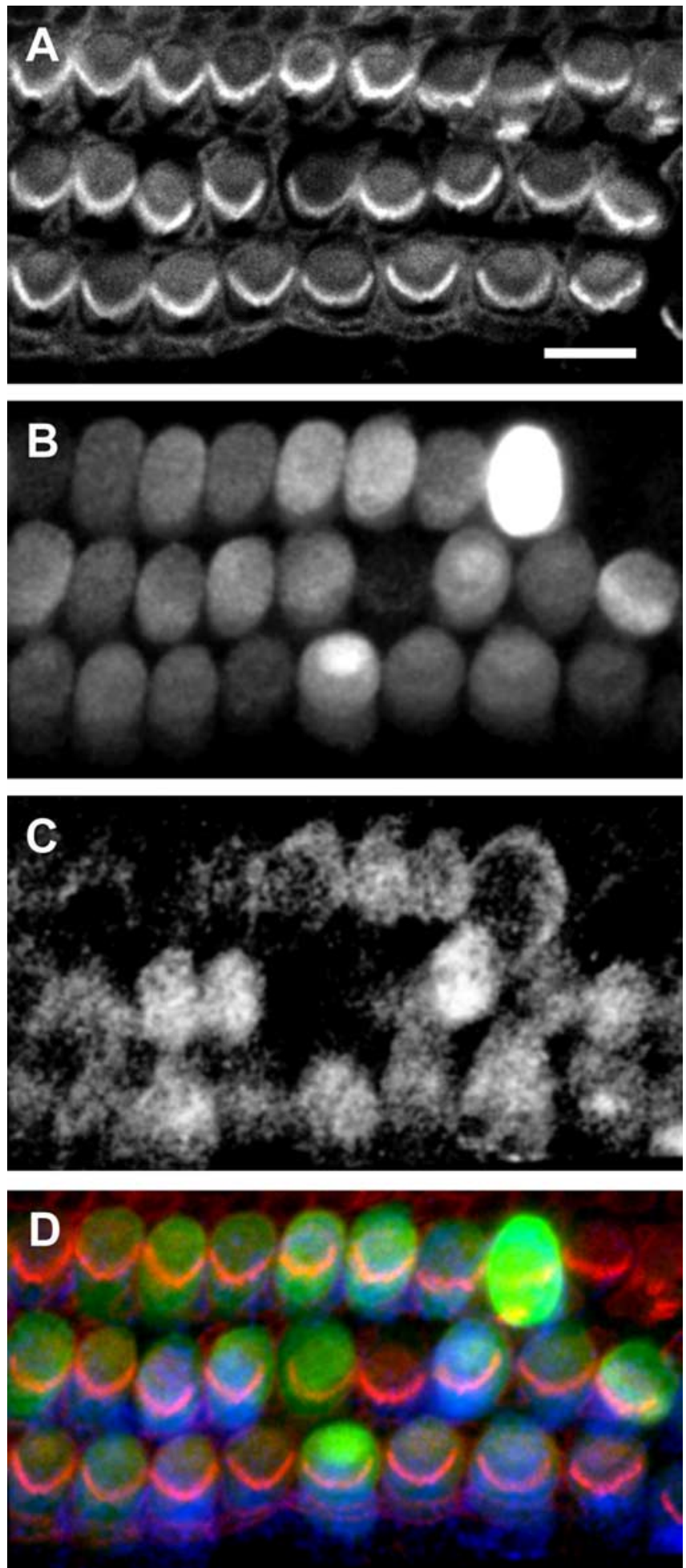

Figure 7. Confocal images of cochlear explant cultures harvested at $\mathrm{P} 0$. The explant was exposed to $5 \times 10^{9}$ particles/ml Ad1-cmv-hKCNQ4-G285S for $4 \mathrm{~h}$ and cultured for $2 \mathrm{~d}$, and then fixed, mounted, and imaged. $A$, Confocal image focused at the hair bundle level showing three rows of outer hair cells stained with phalloidin-Alexa546. $\boldsymbol{B}$, The GFP signal for the same field of hair cells, focused at the cell-body level. $C$, The same field and focal plane showing KCNQ4 immunoreactivity. D, A merge of $A-C$ with actin in red, GFP in green, and KCNQ4 in blue. Scale bar: (in $A) A-D, 10 \mu \mathrm{m}$.

a steepness of $10.6 \mathrm{mV}$, and a $G_{\max }$ of $8.5 \mathrm{nS}$. Together, the two conductances allowed a graded response that spanned almost 100 $\mathrm{mV}$.

Next, we recorded from cells excised at P1 and placed in or- ganotypic culture for 7-10 d. At the same time the culture was generated, we added Ad1-cmv-hKCNQ4-G285S directly to the culture media for $4 \mathrm{~h}$ at a titer of $5 \times 10^{9}$ viral particles $/ \mathrm{ml}$, the same titer used for the culture shown in Figure 7. After a week in culture, we noted that the level of GFP fluorescence had faded to the point that it was difficult to identify GFP-positive cells using conventional fluorescence microscopy in our standard electrophysiology setup. However, when using a more sensitive confocal assay, we were able to confirm a high rate of low-level GFP expression a week postinfection. Because we were able to achieve high KCNQ expression rates ( $\sim 75 \%)$, we assumed that most of the cells in transfected cochlear cultures expressed exogenous hKCNQ4-G285S, despite the decline in GFP fluorescence. The data that follow are consistent with that interpretation. Figure $8 B$ shows a representative family of currents recorded from an outer hair cell of an Ad1-cmv-hKCNQ4-G285S-transfected epithelium. The lack of holding current, lack of instantaneous current, and subsequent deactivation at $-124 \mathrm{mV}$ was in sharp contrast to the currents recorded from the control outer hair cell (Fig. 8A). The tail currents (Fig. $8 C$, circles) were well fit with a single Boltzmann curve with a $V_{(1 / 2)}$ of $-19 \mathrm{mV}$, a steepness of $8.3 \mathrm{mV}$, and a $G_{\max }$ of $7.6 \mathrm{nS}$. Thus, the properties of the current that remained were consistent with the properties of the more positively activating, $G_{\mathrm{K}}$ but inconsistent with the negatively activating $G_{\mathrm{K}, \mathrm{n}}$. We record from five outer hair cells from transfected cochlear cultures, none of which displayed evidence of $G_{\mathrm{K}, \mathrm{n}}$. The whole-cell potassium conductance that remained was well fit by a single Boltzmann relation in each case for which the mean values for the five cells were $V_{(1 / 2)}$ of $-17 \pm 4 \mathrm{mV}$, with a steepness of $11 \pm 2.4$ $\mathrm{mV}$, and $G_{\max }$ of $14 \pm 3 \mathrm{nS}$. In control cells of an equivalent age, $G_{\mathrm{K}, \mathrm{n}}$ had a $V_{(1 / 2)}$ of $-73 \pm 1 \mathrm{mV}$, steepness of $10 \pm 2.6 \mathrm{mV}$, and a whole-cell $G_{\max }$ of $13 \pm 2 \mathrm{nS}(n=3)$.

When we attempted to confirm expression of $G_{\mathrm{K}, \mathrm{n}}$ in control cells excised at $\mathrm{P} 0$ and cultured for $10 \mathrm{~d}$, we found that the current amplitudes were similar to age-matched, acutely excised controls, but that the negative activation range that typifies $G_{\mathrm{K}, \mathrm{n}}$ appeared to be shifted in the positive direction (supplemental Fig. $2 A$, available at www.jneurosci.org as supplemental material). Nonetheless, we confirmed the presence of KCNQ conductances in cultured outer hair cells by application of $200 \mu \mathrm{M}$ the KCNQ channel blocker, linopirdine. We found that the potassium currents were inhibited by $45 \pm 14 \%(n=4)$ (supplemental Fig. $2 B$, available at www.jneurosci.org as supplemental material), consistent with previous reports from acutely excised outer hair cells (Marcotti and Kros, 1999). The current that remained was similar to the whole-cell current recorded from the cells exposed to Ad1cmv-hKCNQ4-G285S: $V_{(1 / 2)}$ of $-19.3 \pm 0.9 \mathrm{mV}$, steepness of $7.7 \pm 2.1 \mathrm{mV}$, and $G_{\max }$ of $6.1 \pm 1.7 \mathrm{nS}(n=3)$. The linopirdinesensitive component was revealed by subtraction of the linopirdine-insensitive currents from the whole-cell currents recorded from the cultured outer hair cells (supplemental Fig. 2C, available at www.jneurosci.org as supplemental material). Interestingly, we discovered that the properties of the linopirdinesensitive currents from cultured hair cells were similar to those of KCNQ4 currents expressed in heterologous cells, which suggested that some labile cofactor, sensitive to the culture conditions, may be responsible for the negative shift in the activation range of KCNQ4 and $G_{\mathrm{K}, \mathrm{n}}$. Chambard and Ashmore (2005) suggested that KCNQ4 phosphorylation via PKA may account for the negative activation range in $G_{K, n}$ in outer hair cells. If so, dynamic modulation of KCNQ4 activation may allow outer hair cells to regulate the properties of $G_{\mathrm{K}, \mathrm{n}}$.

We conclude that the loss of the negatively activating conduc- 
tance in cells exposed to Ad1-cmvhKCNQ4-G285S is consistent with the suggestion that $G_{\mathrm{K}, \mathrm{n}}$ is composed of wildtype KCNQ4 subunits and that its physiological expression can be suppressed by coassembly with dominant-negative KCNQ4 subunits in cultured hair cells.

\section{Functional consequences of KCNQ4-G285S expression}

Because we have shown that KCNQ4G285S can selectively inhibit the physiological expression of $G_{\mathrm{K}, \mathrm{L}}$ and $G_{\mathrm{K}, \mathrm{n}}$, we used the G285S construct as a selective tool to investigate the contribution of the two conductances to sensory signaling in hair cells. For these experiments, we recorded mechanotransduction currents evoked by five-cycle bursts of 1,10 , and $100 \mathrm{~Hz}$ sinusoidal bundle deflections as described previously (Holt et al., 1997). We averaged 16 current records at each frequency and used the resultant waveform as the current stimulus, which was injected in currentclamp mode. The current-clamp stimuli and membrane potential responses (referred to here as receptor potentials) for four representative vestibular hair cells are shown in Figure 9A. There was little qualitative difference between the receptor potentials of GFP-negative and GFP-positive type II hair cells at any of the applied frequencies. We quantified the peakto-peak receptor potentials for six GFP-negative type II cells (squares) and a representative GFP-positive type II cells (Fig. 9B). The lack of significant difference between the two conditions was consistent with the minimal difference we noted in voltageclamp mode for the type II cells. Thus, we conclude that KCNQ4 contributes little to sensory signaling in type II cells in the postnatal mouse utricle.

For the type I cells, there was a striking difference (Fig. 9A). As described previously, the type I receptor potential was significantly attenuated relative to that of the type II cell and its resting membrane potential was hyperpolarized by $15-20 \mathrm{mV}$. Both observations have been attributed to the low input resistance of the type I cell, a substantial portion of which may be attributed to the activation of $G_{\mathrm{K}, \mathrm{L}}$ at rest. Because $G_{\mathrm{K}, \mathrm{L}}$ does not inactivate and the $V_{(1 / 2)}$ of activation averages around $-70 \mathrm{mV}$, it has been hypothesized to contribute significantly to the input resistance. The bottom row of traces (Fig. 9A) show the receptor potentials from a representative type I cell in which we had selectively blocked expression $G_{\mathrm{K}, \mathrm{L}}$ with Ad1-ecd-hKCNQ4-G285S. The input resistance in this cell was $1.3 \mathrm{G} \Omega$ as apposed to $17 \mathrm{M} \Omega$ for the GFPnegative type I cell. The loss of $G_{\mathrm{K}, \mathrm{L}}$ and resultant rise in input resistance had two main effects. The resting potential was depolarized by $27 \mathrm{mV}$ relative to the control cell and the amplitude of the receptor potentials was dramatically enhanced, such that the response more closely resembled those of the type II cells. We quantified the peak-to-peak amplitudes of the receptor potentials and plotted them in Figure $9 C$ for four control type I cells and the GFP + type I cell shown in Figure 9A. The enhanced amplitude of the receptor potential was evident at all frequencies examined, but was most dramatic at frequencies $>20 \mathrm{~Hz}$. We also noted that the mean resting potential was $\sim 14 \mathrm{mV}$ more positive in the GFP + type I cells (Fig. 9D). Based on these data, we conclude that $G_{\mathrm{K}, \mathrm{L}}$, functions to maintain a hyperpolarized resting potential
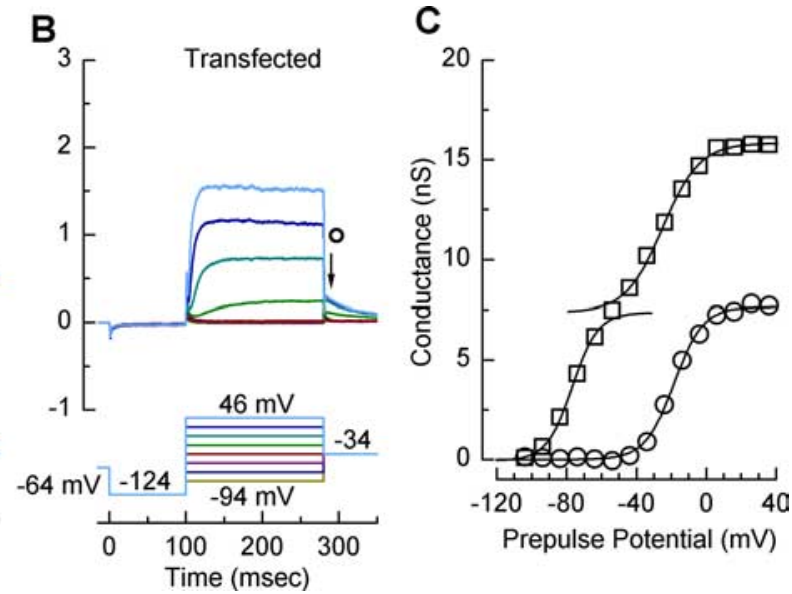

and attenuate the amplitude of the receptor potential in type I, but not type II hair cells.

Next, we investigated the function of $G_{\mathrm{K}, \mathrm{n}}$ in cochlear outer hair cells. To facilitate comparison with vestibular hair cells, we used the same approach and injected prerecorded transduction currents and measured the membrane response in current-clamp mode in control outer hair cells and outer hair cells exposed to Ad1-cmv-hKCNQ4-G285S. In a manner similar to that of the type I vestibular cells, the receptor potentials from outer cells in an infected epithelium were larger than those recorded from a control outer hair cell (data not shown). Plots of the peak-topeak receptor potential amplitude revealed differences of 10-15 $\mathrm{mV}$ between the two conditions. Interestingly, the more dramatic difference was that the transfected outer hair cells had resting potentials $(-33 \pm 7 \mathrm{mV} ; n=5)$ that were significantly depolarized ( $p<0.001)$, by $\sim 20 \mathrm{mV}$ relative to acutely excised control cells $(-53 \pm 10 \mathrm{mV} ; n=6)$, and cultured outer hair cells $(-51 \pm$ $7 \mathrm{mV} ; n=4$ ) (Fig. 9D). We wondered whether KCNQ4 active at rest might similarly contribute to the input resistance in outer hair cells. Control cells had mean input resistances of $203 \pm 119$ $\mathrm{M} \Omega(n=4)$ whereas cells exposed to Ad1-cmv-hKCNQ4-G285S had input resistances that averaged $682 \pm 264 \mathrm{M} \Omega$. Based on these observations, we conclude that KCNQ4 in outer hair cells is active at rest, contributes to the potassium-selective input resistance, which in turn hyperpolarizes the resting potential, and attenuates the amplitude of the receptor potential. The low input resistance also reduces the membrane time constant, which we predict will extend the frequency response to include higher frequencies.

\section{Discussion}

We used adenoviral delivery of a dominant-negative form of the deafness gene KCNQ4 to examine the physiological identity and function of KCNQ-mediated potassium currents in auditory and vestibular hair cells. We generated both singly and multiply deleted vectors. Previously, it was shown that singly deleted vectors compromised hair bundle integrity in transfected cells (Holt et al., 1999). Although the present study did not focus on hair bun- 
A
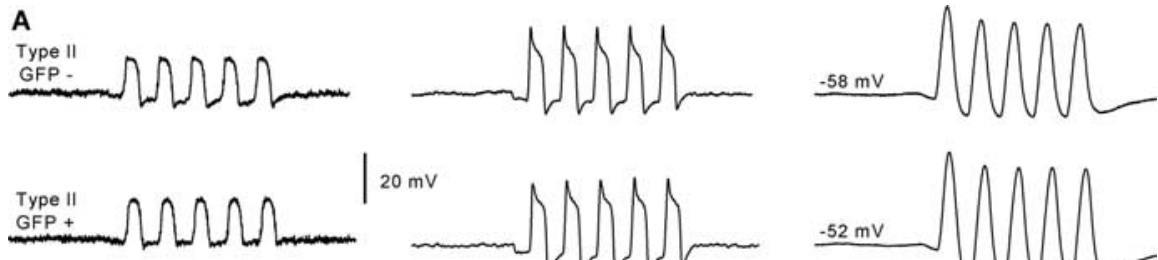

$20 \mathrm{mV}$

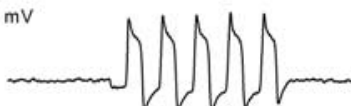

Type

GFP
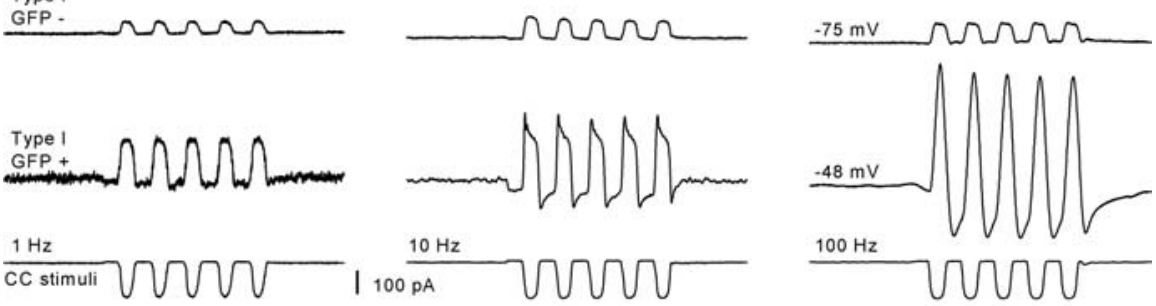

$\frac{1 \mathrm{~Hz}}{\mathrm{CC} \text { stimuli }}$
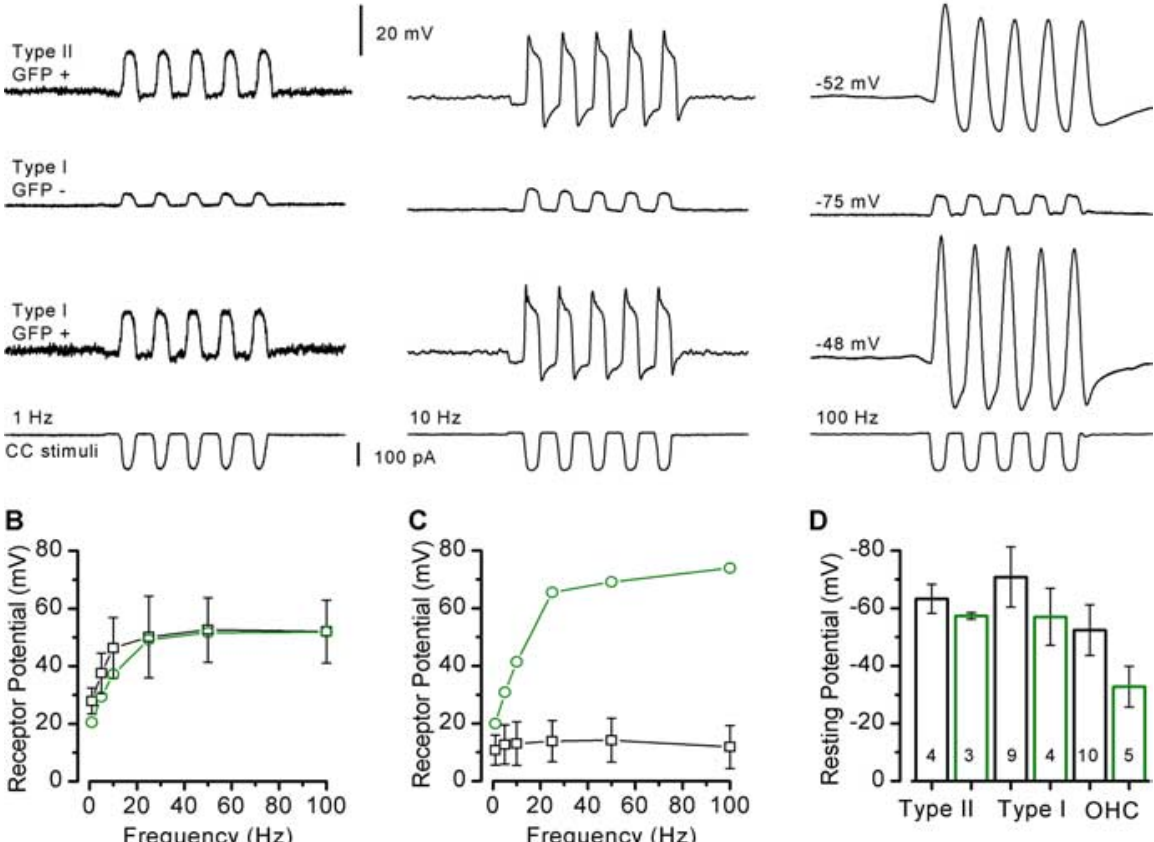

D

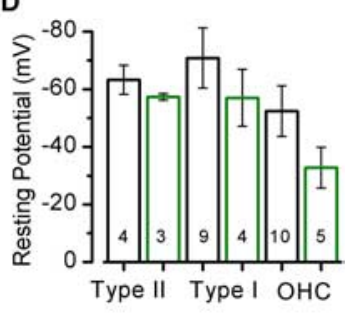

Figure 9. Receptor potentials recorded in current-clamp mode from vestibular hair cells. $\boldsymbol{A}$, Previously recorded transduction currents, evoked by sinewave bundle deflections, were used as current stimuli injected into GFP-negative and -positive type II and type I hair cells. The stimulus protocols shown in the bottom row of traces were delivered at 1, 10, and $100 \mathrm{~Hz}$, as indicated for each column of traces. The cell type and condition is shown on the left for each row of traces and the resting membrane potential is shown on the right. The scale bar applies to all voltage traces. $\boldsymbol{B}$, Mean peak-to-peak receptor potentials were measured for GFP-negative and -positive cells and plotted as a function of stimulus frequency for seven type II hair cells. Error bars are SD. C, Mean peak-to-peak receptor potentials for seven type I hair cells. $D$, Mean \pm SD resting potentials are plotted for six populations of cells: GFP-negative (black) and GFP-positive (green) type II cells (left), type I cells (middle), and outer hair cells (OHC; right). Cultured and acute outer hair cell data were pooled. The number of cells is indicated within each bar.

dle physiology, we felt that it was important to generate multiply deleted vectors because they have no deleterious effects in transfected hair cells (Luebke et al., 2001; Holt, 2002). The similar effect we noted in type I hair cells and lack of effect in type II hair cells transfected with either vector design alleviated concern that adenoviral transfection was the source of the specific inhibition we observed. Confidence in the adenoviral approach was further boosted by the similar results obtained with different promoters, cmv or ecdysone, as well as either biscistronic expression of GFP and KCNQ4 linked via an IRES sequence or separate expression via independent $\mathrm{cmv}$ promoters. Last, although the mouse and human amino acid sequences share $\sim 96 \%$ identity, we felt it was important to confirm coassembly of mouse and human subunits by demonstrating dominant-negative inhibition of hKCNQ4 with mKCNQ4-G285S (Fig. 2B).

\section{Identity of KCNQ4 conductances in hair cells}

Several lines of evidence, including the present study, support the hypothesis that $G_{\mathrm{K}, \mathrm{n}}$ in cochlear outer hair cells is composed of KCNQ4 subunits. There is a strong correlation between the spatiotemporal pattern of KCNQ4 mRNA expression, protein expression (Beisel et al., 2000, 2005), and the acquisition of $G_{\mathrm{K}, \mathrm{n}}$ (Marcotti and Kros, 1999). Although there are no pharmacological compounds that distinguish among KCNQ subunits, linopirdine and XE991 block KCNQ4 in heterologous cells (Sogaard et al., 2001; Chambard and Ashmore, 2005) and $G_{\mathrm{K}, \mathrm{n}}$ in cochlear hair cells (Marcotti and Kros, 1999; Oliver et al., 2003; Wong et al., 2004), consistent with a possible link between the two. Kharkovets et al. (2006) previously generated two mouse lines, one with a truncation that deleted the pore-forming region. The other mouse line carried the G285S point mutation. Outer hair cells from both mouse lines lacked $G_{K, n}$. Our data from transfected outer hair cells also showed a loss of $G_{\mathrm{K}, \mathrm{n}}$ but no inhibition of other conductances. As such, our cochlear outer hair cell data make two contributions. First, by corroborating the previous work, we provide an independent line of evidence supporting the conclusion that $G_{\mathrm{K}, \mathrm{n}}$ includes KCNQ4 subunits. Second, because our data are consistent with the previous work it further validates our adenoviral approach for acute dominant-negative inhibition of hair cells proteins in organotypic cultures of mouse inner ear organs. This raises confidence that the approach can be used to identify KCNQ4-mediated conductances in other cells, particularly those where identification has been more problematic, such as vestibular hair cells.

Since Holt and Corey (1999) first suggested that KCNQ4 may be a component of $G_{K, L}$ in type I hair cells, evidence supporting the hypothesis has been both limited and controversial. Kharkovets et al. (2000) presented immunolocalization data that suggested strong expression of KCNQ4 in mouse vestibular hair cells, a point questioned by Hurley et al. (2006) in rat vestibular organs, but supported by Rocha-Sanchez et al. (2007) in mouse. Our data show a tight temporal correlation in the mouse utricle between the onset of $G_{K, L}$ expression (Géléoc et al., 2004), developmental upregulation of KCNQ4 mRNA expression (Fig. 1A), and the onset of KCNQ4 immunoreactivity (Rocha-Sanchez et al., 2007), all beginning around embryonic day 18 . We also note a parallel rise between the number of type I cells expressing $G_{\mathrm{K}, \mathrm{L}}$ postnatally (Rüsch et al., 1998) and the number of cells with KCNQ4 immunolocalization (Rocha-Sanchez et al., 2007). However, in rat utricle epithelia, Hurley et al. (2006) suggested that KCNQ4 immunoreactivity is mostly restricted to the postsynaptic calyx of type I hair cells, whereas Rocha-Sanchez et al. (2007) showed that KCNQ4 immunoreactivity is retained in hair cells of genetically deafferented mice. Our immunolocalization data (Fig. 3) are consistent with the data from Rocha-Sanchez et al. (2007), because we observed robust KCNQ4 immunoreactivity in organotypic cultures after several days in vitro, well after afferent terminals have decayed.

Pharmacological data implicating functional expression of KCNQ channels in vestibular hair cells has also been difficult to interpret. Significant variability in the efficacy of the KCNQ channel blockers linopirdine and XE991 as a function of region, developmental stage, and animal model, has been reported previously (Rennie et al., 2001; Hurley et al., 2006). Rennie et al. (2001) noted effects of the two drugs on both type I and type II hair cells from gerbil and pigeon vestibular organs and suggested 
that KCNQ subunits may contribute to the potassium conductances in those cells. In rat utricle type I hair cells, Hurley et al. (2006) described a heterogeneous population of potassium conductances and suggested that they may consist of KCNQ channels as well as ether-a-go-go-related (erg) channels based on RT-PCR, pharmacology, and immunolocalization.

Our data showing robust dominant-negative inhibition of $G_{\mathrm{K}, \mathrm{L}}$ in type I cells, but no significant inhibition of $G_{\mathrm{DR}}$ in type II cells, support the hypothesis that $G_{\mathrm{K}, \mathrm{L}}$ consists of KCNQ4 subunits or subunits that can coassemble with KCNQ4. Kubisch et al. (1999) examined expression of KCNQ1-4 in heterologous cells and concluded that the only subunit that coassembled with KCNQ4 was KCNQ3 and, moreover, that KCNQ3 homomeric channels yielded minimal conductance. Thus, we conclude that $G_{\mathrm{K}, \mathrm{L}}$ may consist of KCNQ4 and/or KCNQ3/Q4 heteromers, but we cannot exclude the possibility that other, yet unknown KCNQ4 coassembly partners may contribute, perhaps KCNQ5 or erg subunits (Ehrlich et al., 2004; Hurley et al., 2006). Last, we propose that some of the physiological and pharmacological variability of KCNQ4 mediated conductances among species, organs, regions and developmental stages may be attributed to variability in the expression pattern of KCNQ4 coassembly partners or KCNQ4 alternative splice forms (Beisel et al., 2005; RochaSanchez et al., 2007), the later also detected here (Fig. $1 B$ ).

\section{Function of KCNQ4 conductances in hair cells}

The specific suppression of $G_{\mathrm{K}, \mathrm{n}}$ and $G_{\mathrm{K}, \mathrm{L}}$ with KCNQ4-G285S that we have demonstrated allows for acute dominant-negative inhibition $G_{\mathrm{K}, \mathrm{n}}$ and $G_{\mathrm{K}, \mathrm{L}}$ to study their functional contribution to sensory processing in hair cells and also provides insight into the etiology of the KCNQ4-associated dominant-progressive hearing loss, DFNA2. We found that inhibition of $G_{\mathrm{K}, \mathrm{n}}$ in outer hair cells had two significant consequences. The loss of $G_{\mathrm{K}, \mathrm{n}}$ on at rest resulted in outer hair cell receptor potentials that were $\sim 38 \%$ larger, depending on the frequency, which may drive enhanced prestin-dependent somatic motility and feedback to further enhance the receptor potential. In addition, we noted that outer hair cell resting potentials were significantly depolarized, to $-33 \pm$ $7.1 \mathrm{mV}$. Both the amplified receptor potential and depolarized resting potential bring the hair cell membrane potential well into the active range of the noninactivating calcium channels that typify inner-ear hair cells (Dou et al., 2004). Thus, our data are consistent with the hypothesis that mutations in KCNQ4 cause a decrease in outer hair cell resting conductance, which in turn allows for accumulation of intracellular calcium, likely the proximal cause of outer hair cell death. Although others have suggested that loss of $G_{\mathrm{K}, \mathrm{n}}$ function in inner hair cells is the cause of DFNA2 hearing loss (Oliver et al., 2003), Kharkovets et al. (2006) suggested that outer hair cell degeneration was more likely because inner hair cells of KCNQ4 mutant mice retained normal functions. As such, we did not examine the role of $G_{\mathrm{K}, \mathrm{n}}$ in inner hair cells, however, our data are consistent with loss of $G_{K, n}$ in outer hair cells as a source of auditory dysfunction.

Although KCNQ4 is strongly expressed in vestibular cells, it is surprising that neither mice nor humans with KCNQ4 mutations suffer from significant vestibular deficits. Although KCNQ4 can contribute to $G_{\mathrm{K}, \mathrm{L}}$ in type I vestibular hair cells, loss of the conductance did not depolarize the cells to the same extent as loss of $G_{\mathrm{K}, \mathrm{n}}$ in outer hair cells, perhaps because type I cells also express inward rectifier conductances (Rüsch et al., 1998), which may compensate by allowing those cells to remain more hyperpolarized. Furthermore, because the dominant-negative form of KCNQ4 only had a significant effect in type I cells, type II cells or approximately one-half of the hair cells in vestibular epithelia (Desai et al., 2005), retained normal function. It is interesting to note that the only vestibular phenotype, reported in $\sim 25 \%$ of DFNA2 patients, is a hyperactive vestibular-ocular reflex (De Leenheer et al., 2002), which we suggest may follow from the exaggerated receptor potentials that we observed in type I hair cells that lacked $G_{\mathrm{K}, \mathrm{L}}$ (Fig. $9 A, D$ ).

We conclude that KCNQ4 contributes to the M-like conductances $G_{\mathrm{K}, \mathrm{n}}$ and $G_{\mathrm{K}, \mathrm{L}}$ in outer hair cells and type I hair cells, respectively. In other systems, $\mathrm{M}$-conductances are modulated by signaling cascades including those activated by muscarinic acetylcholine receptors (Brown and Adams, 1980). Because efferent feedback to hair cells organs may be transmitted via acetylcholine (Fuchs, 2002), and because several studies have reported that $G_{\mathrm{K}, \mathrm{n}}$ (Jagger and Ashmore, 1999), $G_{\mathrm{K}, \mathrm{L}}$ (Chen and Eatock, 2000), and KCNQ4 (Chambard and Ashmore, 2005) are modulated by second-messenger cascades, we suggest that efferent innervation of inner ear organs may allow hair cells the ability to modulate their responses to auditory and vestibular stimulation.

\section{References}

Amalfitano A, Hauser MA, Hu H, Serra D, Begy CR, Chamberlain JS (1998) Production and characterization of improved adenovirus vectors with the E1, E2b, and E3 genes deleted. J Virol 72:926-933.

Beisel KW, Nelson NC, Delimont DC, Fritzsch B (2000) Longitudinal gradients of KCNQ4 expression in spiral ganglion and cochlear hair cells correlate with progressive hearing loss in DFNA2. Brain Res Mol Brain Res 82:137-149.

Beisel KW, Rocha-Sanchez SM, Morris KA, Nie L, Feng F, Kachar B, Yamoah EN, Fritzsch B (2005) Differential expression of KCNQ4 in inner hair cells and sensory neurons is the basis of progressive high-frequency hearing loss. J Neurosci 25:9285-9293.

Brown DA, Adams PR (1980) Muscarinic suppression of a novel voltagesensitive $\mathrm{K}^{+}$current in a vertebrate neurone. Nature 283:673-676.

Chambard JM, Ashmore JF (2005) Regulation of the voltage-gated potassium channel KCNQ4 in the auditory pathway. Pflugers Arch 450:34-44.

Chen JW, Eatock RA (2000) Major potassium conductance in type I hair cells from rat semicircular canals: characterization and modulation by nitric oxide. J Neurophysiol 84:139-151.

Corey DP, Garcia-Anoveros J, Holt JR, Kwan KY, Lin SY, Vollrath MA, Amalfitano A, Cheung EL, Derfler BH, Duggan A, Geleoc GS, Gray PA, Hoffman MP, Rehm HL, Tamasauskas D, Zhang DS (2004) TRPA1 is a candidate for the mechanosensitive transduction channel of vertebrate hair cells. Nature 432:723-730.

De Leenheer EM, Huygen PL, Coucke PJ, Admiraal RJ, van Camp G, Cremers CW (2002) Longitudinal and cross-sectional phenotype analysis in a new, large Dutch DFNA2/KCNQ4 family. Ann Otol Rhinol Laryngol 111:267-274.

Desai SS, Zeh C, Lysakowski A (2005) Comparative morphology of rodent vestibular periphery. I. Saccular and utricular maculae. J Neurophysiol 93:251-266.

Dou H, Vazquez AE, Namkung Y, Chu H, Cardell EL, Nie L, Parson S, Shin HS, Yamoah EN (2004) Null mutation of $\alpha 1 \mathrm{D} \mathrm{Ca}^{2+}$ channel gene results in deafness but no vestibular defect in mice. J Assoc Res Otolaryngol 5:215-226.

Ehrlich JR, Pourrier M, Weerapura M, Ethier N, Marmabachi AM, Hebert TE, Nattel S (2004) KvLQT1 modulates the distribution and biophysical properties of HERG. A novel alpha-subunit interaction between delayed rectifier currents. J Biol Chem 279:1233-1241.

Fuchs P (2002) The synaptic physiology of cochlear hair cells. Audiol Neurootol 7:40-44.

Géléoc GS, Holt JR (2003) Developmental acquisition of sensory transduction in hair cells of the mouse inner ear. Nat Neurosci 6:1019-1020.

Géléoc GS, Risner JR, Holt JR (2004) Developmental acquisition of voltagedependent conductances and sensory signaling in hair cells of the embryonic mouse inner ear. J Neurosci 24:11148-11159.

He TC, Zhou S, da Costa LT, Yu J, Kinzler KW, Vogelstein B (1998) A simplified system for generating recombinant adenoviruses. Proc Natl Acad Sci USA 95:2509-2514. 
Hodges BL, Serra D, Hu H, Begy CA, Chamberlain JS, Amalfitano A (2000) Multiply deleted [E1, polymerase-, and pTP-] adenovirus vector persists despite deletion of the preterminal protein. J Gene Med 2:250-259.

Holt JR (2002) Viral-mediated gene transfer to study the molecular physiology of the mammalian inner ear. Audiol Neurootol 7:157-160.

Holt JR, Corey DP (1999) Ion channel defects in hereditary hearing loss. Neuron 22:217-219.

Holt JR, Corey DP, Eatock RA (1997) Mechanoelectrical transduction and adaptation in hair cells of the mouse utricle, a low-frequency vestibular organ. J Neurosci 17:8739-8748.

Holt JR, Johns DC, Wang S, Chen ZY, Dunn RJ, Marban E, Corey DP (1999) Functional expression of exogenous proteins in mammalian sensory hair cells infected with adenoviral vectors. J Neurophysiol 81:1881-1888.

Hougaard C, Klaerke DA, Hoffmann EK, Olesen SP, Jorgensen NK (2004) Modulation of KCNQ4 channel activity by changes in cell volume. Biochim Biophys Acta 1660:1-6.

Housley GD, Ashmore JF (1992) Ionic currents of outer hair cells isolated from the guinea-pig cochlea. J Physiol (Lond) 448:73-98.

Hurley KM, Gaboyard S, Zhong M, Price SD, Wooltorton JR, Lysakowski A,

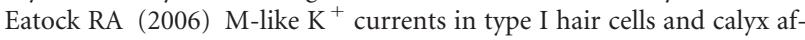
ferent endings of the developing rat utricle. J Neurosci 26:10253-10269.

Jagger DJ, Ashmore JF (1999) Regulation of ionic currents by protein kinase A and intracellular calcium in outer hair cells isolated from the guinea-pig cochlea. Pflugers Arch 437:409-416.

Johns DC, Marx R, Mains RE, O’Rourke B, Marban E (1999) Inducible genetic suppression of neuronal excitability. J Neurosci 19:1691-1697.

Judice TN, Nelson NC, Beisel CL, Delimont DC, Fritzsch B, Beisel KW (2002) Cochlear whole-mount in situ hybridization: identification of longitudinal and radial gradients. Brain Res Brain Res Protoc 9:65-76.

Kharkovets T, Hardelin JP, Safieddine S, Schweizer M, El-Amraoui A, Petit C, Jentsch TJ (2000) KCNQ4, a $\mathrm{K}^{+}$channel mutated in a form of dominant deafness, is expressed in the inner ear and the central auditory pathway. Proc Natl Acad Sci USA 97:4333-4338.

Kharkovets T, Dedek K, Maier H, Schweizer M, Khimich D, Nouvian R, Vardanyan V, Leuwer R, Moser T, Jentsch TJ (2006) Mice with altered KCNQ4 $\mathrm{K}^{+}$channels implicate sensory outer hair cells in human progressive deafness. EMBO J 25:642-652.

Kubisch C, Schroeder BC, Friedrich T, Lutjohann B, El-Amraoui A, Marlin S,
Petit C, Jentsch TJ (1999) KCNQ4, a novel potassium channel expressed in sensory outer hair cells, is mutated in dominant deafness. Cell 96:437-446.

Luebke AE, Steiger JD, Hodges BL, Amalfitano A (2001) A modified adenovirus can transfect cochlear hair cells in vivo without compromising cochlear function. Gene Ther 8:789-794.

Marcotti W, Kros CJ (1999) Developmental expression of the potassium current $I_{\mathrm{K}, \mathrm{n}}$ contributes to maturation of mouse outer hair cells. J Physiol (Lond) 520:653-660.

Oliver D, Knipper M, Derst C, Fakler B (2003) Resting potential and submembrane calcium concentration of inner hair cells in the isolated mouse cochlea are set by KCNQ-type potassium channels. J Neurosci 23:2141-2149.

Rennie KJ, Weng T, Correia MJ (2001) Effects of KCNQ channel blockers on $\mathrm{K}(+)$ currents in vestibular hair cells. Am J Physiol Cell Physiol 280:C473-C480.

Rocha-Sanchez SM, Morris KA, Kachar B, Nichols D, Fritzsch B, Beisel KW (2007) Developmental expression of Kcnq4 in vestibular neurons and neurosensory epithelia. Brain Res 1139:117-125.

Rüsch A, Eatock RA (1996) A delayed rectifier conductance in type I hair cells of the mouse utricle. J Neurophysiol 76:995-1004.

Rüsch A, Lysakowski A, Eatock RA (1998) Postnatal development of type I and type II hair cells in the mouse utricle: acquisition of voltage-gated conductances and differentiated morphology. J Neurosci 18:7487-7501.

Schroder RL, Jespersen T, Christophersen P, Strobaek D, Jensen BS, Olesen SP (2001) KCNQ4 channel activation by BMS-204352 and retigabine. Neuropharmacology 40:888-898.

Sogaard R, Ljungstrom T, Pedersen KA, Olesen SP, Jensen BS (2001) KCNQ4 channels expressed in mammalian cells: functional characteristics and pharmacology. Am J Physiol Cell Physiol 280:C859-C866.

Trussell L (2000) Mutant ion channel in cochlear hair cells causes deafness. Proc Natl Acad Sci USA 97:3786-3788.

Wong WH, Hurley KM, Eatock RA (2004) Differences between the negatively activating potassium conductances of mammalian cochlear and vestibular hair cells. J Assoc Res Otolaryngol 5:270-284.

Zheng J, Madison LD, Oliver D, Fakler B, Dallos P (2002) Prestin, the motor protein of outer hair cells. Audiol Neurootol 7:9-12. 